\title{
Петро Ричков
}

\section{АРХІТЕКТУРНІ ПРОЕКТИ ОСТРОЗЬКОГО ЄЗУЇТСЬКОГО КОЛЕГУМУ: ТВОРЧІ ВЕРСІЇ ДЖАКОМО БРІАНО}

Острозькому єзуїтському колегіуму належить поважне місце в історії архітектури Речі Посполитої першої половини XVII ст. Незважаючи на цілковите знищення об'єкту ще у часи Російської імперії, особливостям його заснування та розбудови присвячена ціла низка аналітичних праць, зокрема, Сжи Пашенди ${ }^{1}$, Ріхарда Бьозеля ${ }^{2}$, Марії Бриковської, Анджея Барановського ${ }^{4}$, Анджея Бетлея ${ }^{5}$ та інших дослідників. Неодноразово торкався цих питань і автор даної статті ${ }^{6}$. Тим не менш, генеза та характеристики архітектурного комплексу отців єзуїтів в Острозі виглядають все ще достатньо привабливими для глибшого аналізу, - перш за все, з точки зору його формування на ранній стадії, позначеній активними творчими пошу-

${ }^{1}$ Paszenda J. Problem stylu w architekturze jezuickiej // Biuletyn Historii Sztuki. - Warszawa, 1967. - № 2. - S. 146-156; Paszenda J. Biografia architekta Giacomo Briano // Biuletyn Historii Sztuki. - Warszawa, 1967. - № 1. - S. 10-17; Paszenda J. Architektura kolegium jezuitów w Ostrogu // Sztuka pograniczy Rzeczypospolitej w okresie nowożytnym od XVI do XVIII wieku. Warszawa, 1998. - S. 285-303; Paszenda J. Architektura kolegium jezuitów w Ostrogu // Budowle jezuickie w Polsce XVI-XVIII w. - Kraków, 2000. - T. 2. - S. 305-317.

${ }^{2}$ Bösel R. Typus und Tradition in der Baukultur gegenreformatischer Orden // Römische Historische Mitteilungen. - Wien, 1989. - Vol. 31. - S. 239-253; Bösel R. Giacomo Briano, der Architekt der Lemberger Jesuitenkirche // Міжнародний 2-й конгрес україністів (Львів, 22-26 серпня 1993 р.: історіографія українознавства, етнологія, культура). - Львів, 1994. - С. 184-189.

${ }^{3}$ Brykowska M. Kościół jezuitów w Łucku i architektura zakonu jezuitów na Wołyniu i Podolu w 1. połowie XVII wieku // Sztuka kresów wschodnich. - Kraków, 1996. - T. 2. - S. 65-84.

${ }^{4}$ Baranowski A. Rola kościołów jezuickich w rozwoju architektury Wielkiego Kśięstwa Litewskiego // Podług nieba i zwyczaju polskiego. Studia z historii architektury, sztuki i kulturas ofiarowane Adamowi Miłobędskiemu. - Warszawa, 1988. - S. 286-295.

${ }^{5}$ Betlej A. Appunti sui disegni del gesuita Giacomo Briano // Il disegno di architectura. - Roma, 2003. - № 27. - P. 17-24; Betlej A. "Niech przyjdzie tu Witruwiusz wraz ze swoimi następcami". Kilka uwag na temat kościoła i kolegium Jezuitów w Ostrogu // Roczniki Humanistyczne KUL. Historia Sztuki. - Lublin, 2006. - T. 54, zesz. 4. - S. 189-224.

${ }^{6}$ Ричков П. До історії спорудження єзуїтського колегіуму в Острозі // Пам'ятки сакрального мистецтва Волині на межі тисячоліть. Науковий збірник. - Луцьк, 2000. - Вип. 7. С. 76-81; Ричков П. Острозька спадщина архітектора Джакомо Бріано // Пам'ятки сакрального мистецтва Волині на межі тисячоліть. Науковий збірник. - Луцьк, 2000. - Вип. 7. С. 81-84; Ричков П., Луи В. Архітектурно-мистецька спадщина князів Острозьких. - Київ, 2002. - 168 с.; Ричков П. NON OMNIS MORIAR. Архітектура в культурній праці князів Острозьких. Монографія. - Рівне, 2011. - 142 с. 
ками італійського майстра i, між іншим, члена Товариства Ісуса Джакомо Бріано (Giacomo Briano, Jacobus Brianus, Jakub Bryan) (бл. 1589-1649)7.

Архітектор прибув до Острога на початку вересня 1630 року і майже безвиїзно працював тут до весни 1632 року ${ }^{8}$. Запрошений особисто власницею міста Анною-Алоїзою Ходкевич як досвідчений майстер ${ }^{9}$, він виконав більше десятка проектних варіантів колегіуму, однак так і не дійшов згоди з патронесою. У підсумку, співпраця між аристократкою та архітектором була припинена. Втім, до нашого часу дійшла значна частина проектів Бріано, даючи цікаву поживу для детальнішого аналізу його творчої спадщини.

Варто зауважити, що «технологія» реалізації архітектурних ініціатив Товариства Ісуса у цей час передбачала постійний адміністративний контроль над спорудженням нових осель, особливо у віддалених провінціях. Раніше замовнику надсилався готовий проект, розроблений у Римі орденськими спеціалістами. Та через неврахування місцевих умов і брак фахового нагляду за втіленням задуму у життя деякі зі зведених споруд мали істотні вади. Тому згодом проектна функція все частіше покладалася на довірених архітекторів-єзуїтів, котрі мали розробляти і реалізовувати проекти безпосередньо на місцях. При цьому основним їхнім завданням було функціональне забезпечення діяльності осель в декількох головних аспектах: урбаністичному (вибір зручної ділянки), літургійному (побудова костелу), дидактичному (зведення школи-колегіуму) та побутовому (спорудження келій для помешкань, господарських приміщень). Разом з тим, відбувалося формування певних архітектурно-стилістичних преференцій Товариства, яке з часом вилилося навіть в появу такої неоднозначної дефініції як «єзуїтський стиль» ${ }^{10}$.

Головним, а часто і єдиним видом проектного документу для погодження з орденським керівництвом слугували лаконічні плани споруд, виконані в досить дрібному масштабі. Відомі окремі приклади укладання одночасно декількох проектних версій, як правило, - на початковій стадії ${ }^{11}$. Рідше зустрічається інформація про виконання моделей (макетів), хоча в ренесансну добу це був досить розповсюджений спосіб попереднього «програму-

\footnotetext{
${ }^{7}$ Poplatek J., Paszenda J. Słownik jezuitów artystów. - Kraków, 1972. - S. 89-93.

${ }^{8}$ Ibidem. - S. 90-91.

${ }^{9}$ В листі до орденського генерала Анна-Алоїза Ходкевич мотивувала свій вибір тим, що раніше архітектор успішно працював на будівництві єзуїтського костелу в Луцьку.

${ }^{10}$ Paszenda J. Losy tak zwanego stylu jezuickiego // Biuletyn Historii Sztuki. - Warszawa, 2000. - № 1-2. - S. 163-171.

${ }^{11}$ Наприклад, симетричний та асиметричний варіанти розпланування єзуїтського колегіуму у Львові були укладені в 1609 році і надіслані на розгляд до Риму. Затверджено для реалізації асиметричний варіант. Див.: Ричков П. Формування архітектурного комплексу Товариства Iсуса у Львові (за іконографічними джерелами XVII-XVIII століть) // Записки Наукового товариства ім. Шевченка. - Львів, 2008. - Т. 255 [Праці Комісії архітектури та містобудування]. - С. 45.
} 
вання» нового будівництва ${ }^{12}$. Унікальна ситуація склалася 3 креслениками Д. Бріано для Острога. Серед тих, що дійшли до наших часів, переважають обмірні та проектні плани, тоді як фасади представлені лише поодинокими екземплярами, нерідко навіть без конкретної містобудівної локалізації. Більше того, особливості уцілілої авторської графіки засвідчують високу імовірність наявності серед них окремих вторинних копій.

Передісторія будівництва. Перші єзуїти поселилися в Острозі на початку 1620 -х, а в 1623 році вони вже отримали власний конфесіонал у тутешньому фарному костелі. Членам Товариства вдалося заручитися дієвою підтримкою власниці частини міста Анни-Алоїзи Ходкевич. За деякими свідченнями, оселити єзуїтів в сусідньому містечку Межиріч планував ще раніше їі дядько, краківський каштелян Януш Острозький, але з невідомих причин він відмовився від свого задуму і згодом побудував тут навколо давнього православного храму св. Трійці францисканський монастир ${ }^{13}$.

27 липня 1624 року княжна Анна-Алоїза оформила відповідним актом рішення про заснування в Острозі єзуїтського колегіуму і забезпечила його низкою щедрих пожертв ${ }^{14}$. У фундаційному документі зазначено, що заклад створюється в пам'ять про померлих предків з роду кн. Острозьких і чоловіка - великого литовського гетьмана Яна-Кароля Ходкевича. А відтак ця святиня, на думку деяких дослідників, нібито розглядався нею як «величний монумент войовничому католицизму, Речі Посполитої і як охоронець Віри» ${ }^{15}$. Про її надання єзуїтам свідчать статистичні дані, обраховані Олексієм Барановичем. Так, станом на 1629 рік колегіум володів 19 селами, найбільшими з-поміж яких були Княгинин (124 дими) та Мощаниця (85 димів). Ще 399 господарств підданих нараховувалося в розташованих навколо цих двох центрів П'ятигорщині, Могилянах, Острові, Мартинові, Білобережжі, Уїзді, Зарудді, Спасові, Бодаках, Шарварках, Замлинні, Волиці, Нараєві, Курганах, Мишківцях, Волосківцях, а також у Новогородчичах ${ }^{16}$. Місійну резиденцію для Товариства Ісуса княжна Анна-Алоїза побудувала в мурах княгининського замку, фрагмент якого дійшов до наших часів ${ }^{17}$.

\footnotetext{
${ }^{12}$ Architekturmodelle der Renaissance: Die Harmonie des Bauens von Alberti bis Michelangelo / Hrsg. von Bernd Evers. - München-New York, 1995. - 416 s.

13 Левиџкий О. Анна-Алоиза, княжна Острожская // Киевская старина. - Киев, 1883. Т. 7, ноябрь. - С. 343.

${ }^{14}$ Zatęski S. Jezuici w Polsce. - Lwów, 1905. - T. 4, cz. 3. - S. 1251-1252.

15 Betlej A. Jesuits architecture in Polish-Lithuanian Commonwealth in 1564-1772 // La arquitectura jesuítica. Actas del Simposio Internacional, Zaragoza, 9, 10 y 11 de diciembre de 2010. - Zaragoza, 2012. - P. 288.

${ }^{16}$ Баранович О. Залюднення Волинського воєводства в першій половині XVII ст. - Київ, 1930. - C. 31.

${ }^{17}$ Betlej A. "Niech przyjdzie tu Witruwiusz wraz ze swoimi następcami". Kilka uwag na temat kościoła i kolegium Jezuitów w Ostrogu // Roczniki Humanistyczne KUL. Historia Sztuki. - Lublin, 2006. - T. 54, zesz. 4. - S. 189-224.
} 
Виношуючи плани нового грандіозного будівництва, єзуїти завчасно звели в Острозі тимчасове примішення для колегіуму з каплицею та криптою для поховань. Перший поверх цієї споруди був мурований, а другий дерев'яний ${ }^{18}$. Як стверджує Станіслав Заленський, вона була завершена досить швидко, і 10 листопада 1626 року відбулося урочисте відкриття Острозької резиденції разом зі школою ${ }^{19}$. В перший академічний рік тут нараховувалося всього кілька учнів, тому навіть не було сформовано класів, дітей навчали індивідуально. Але вже в наступному році ситуація змінилася на краще. Помітно зросло число учнів, з'явилися класи граматики та риторики, резиденція отримала статус колегіуму. Станом на 1632 рік в острозькому осередку Товариства Ісуса постійно мешкало 30 єзуїтів, з них чотири професори та три магістри ${ }^{20}$.

Просторова локалізація колегіуму. Земельна ділянка, виділена фундаторкою під майбутній колегіум, розташовувалася в північно-східній частині Острога й безпосередньо примикала до міського муру на схід від Татарської брами ${ }^{21}$. Ця територія була зайнята міщанською забудовою, спеціально консолідованою Анною-Алоїзою задля нового будівництва. Важливою особливістю ділянки для просторової локалізації об'єкту в міському середовищі було іiї безпосереднє примикання до північно-східного наріжного кута ринкової площі. Практика наближення єзуїтських осель до ринкових площ була доволі поширеною, на що вказують приклади Вінниці, Луцька, Бара. Існував, щоправда, й істотний недолік цієї ділянки - іï низинне розташування, що, з огляду на перезволоження грунту, в подальшому мало прикрі наслідки для конструктивної стабільності будівель.

Відомі три проекти колегіуму, виконані попередниками Д. Бріано ще перед його прибуттям до Острога 22. Усі вони були укладені лише у вигля-

${ }^{18}$ У 1644 році ця споруда була розібрана, а будівельний матеріал використано для зведення нового укріпленого двору, в якому часом мешкала сама княжна (Załęski S. Jezuici w Polsce. Lwów, 1905. - T. 4, cz. 3. - S. 1255). Судячи 3 картографічних джерел, це був доволі розлогий палацово-господарський комплекс на правому підвищеному березі у верхів'ях річки Стубла, на відстані близько 30 кілометрів від Острога.

${ }^{19}$ Існує переказ, що єзуїти 3 самого початку отримали від фундаторки колишній будинок Острозької академії, яку вона закрила у 1624 році (Митрополит Іларіон. Князь Костянтин Острозький і його культурна праця. - Б.м., 1992. - С. 127). 3 цієї недоведеної версії випливає, що свою першу резиденцію єзуїти лише перебудували, а не звели «з нуля». Однак, зважаючи на той факт, що Острозька академія знаходилася поблизу замку, на так званому «пригородку», це твердження виглядає помилковим.

${ }^{20}$ Załęski S. Jezuici w Polsce. - Lwów, 1905. - T. 4, cz. 3. - S. 1255.

21 Завдячуючи обмірному кресленню, виконаному архітектором в 1632 році, маємо найстаріший фіксаційний план цієї унікальної споруди. Фрагмент плану див.: Ричков П. Ренесансні аттики у формуванні архітектурної ідентичності культурного домену Острозьких // Острозька давнина. - Остріг, 2017. - Вип. 4. - С. 126.

22 Ричков П.А. Початковий етап проектування та будівництва єзуїтського монастиря в Острозі // Остріг на порозі 900-річчя. Матеріали IV-ої науково-краєзнавчої конференції. Остріг, 1993. - С. 140-142. 
ді поземних планів в межах відведеної земельної ділянки. Принаймні, нам не відомі інші види архітектурної графіки (фасади та розрізи) стосовно цих проектних версій.

Найдавнішим можна вважати графічний документ, що містить авторську ремарку «Ichnographia Collegii Ostrogiensis Romae confecta» ${ }^{23}$, яка засвідчує його виконання в римському офісі Товариства (рис.1А). Очевидно, він був укладений невдовзі після заяви Анни-Алоїзи про бажання бачити в Острозі постійний осідок Товариства Ісуса. Зовнішні габарити колегіуму у цьому первісному варіанті були безпосередньо допасовані до неправильної в плані, чотирикутної земельної ділянки. Її північна частина, яка безпосередньо прилягала до міського муру, залишалася вільною від забудови. Сама будівля колегіуму разом 3 костелом характеризувалася доволі компактним розплануванням. Поряд з костелом передбачалися два автономних дворових простори. При цьому явно домінувала зона житлово-господарська, тоді як для школи був відведений значно менший за розмірами трикутний двір. Тринавовий костел базилікального типу своїм головним фасадом зорієнтований був у південно-західному напрямку на сусідню ринкову площу.

Порівнюючи графічний почерк цього проекту 3 проектами єзуїтських садиб в інших містах Європи, його автором можна визнати орденського архітектора Крістофа Грінбергера ${ }^{24}$. Манера креслень цього майстра була типовою, незалежно від місця, для якого вони виконувалися. Як приклад властивої йому манери можна навести проект єзуїтського колегіуму в французському місті Оріяк (Aurillac), затверджений орденським архітектором Мартеланжем 15 січня 1621 року ${ }^{25}$.

Острозький проект Ірінбергера, що виглядає надто схематичним, не був прийнятий до реалізації. Його гіпотетична тривимірна реконструкція (рис. 1В) справді видається занадто компактною, а в композиційному сенсі спрощеною і навіть примітивною, хоча, звичайно, існує можливість композиційної активізації головного фасаду за рахунок двох симетричних веж храму. Якою мірою цей проектний документ був використаний на стадії закладання підмурків, залишається невідомим. Утім, локалізація костелу 3 орієнтацією на ринкову площу виявилася доволі логічною.

Інший проект, який хронологічно можна вважати другим, в інвентарному описі не містить згадки про автора і датується 1625 роком $^{26}$ (рис. 2А). Більша

\footnotetext{
${ }^{23}$ Vallery-Radot $J$. Le recueil de plans d'édifices de la Compagnie de Jésus conserve à la Bibliothèque Nationale de Paris. - Romae, 1960. - P. 345 (Hd-4a, 70).

${ }^{24}$ Paszenda J. Problem stylu w architekturze jezuickiej... - P.150; Il.2.: C, D.

${ }^{25}$ Див. детальніше: Bösel $R$. La ratio aedificiorum di un'istituzione globale tra autorità centrale e infinità del territorio // La arquitectura jesuítica. Actas del Simposio Internacional, Zaragoza, 9, 10 y 11 de diciembre de 2010. - Zaragoza, 2012. - P. 62. (Fig. 21. P. Christophorus Grienberger. Progetto per la chiesa gesuitica di Aurillac, approvato il 15 gennaio 1621, Étienne Martellange).

${ }^{26}$ Vallery-Radot J. Le recueil de plans d'édifices de la Compagnie de Jésus... - P. 343 (Hd-4, 161).
} 


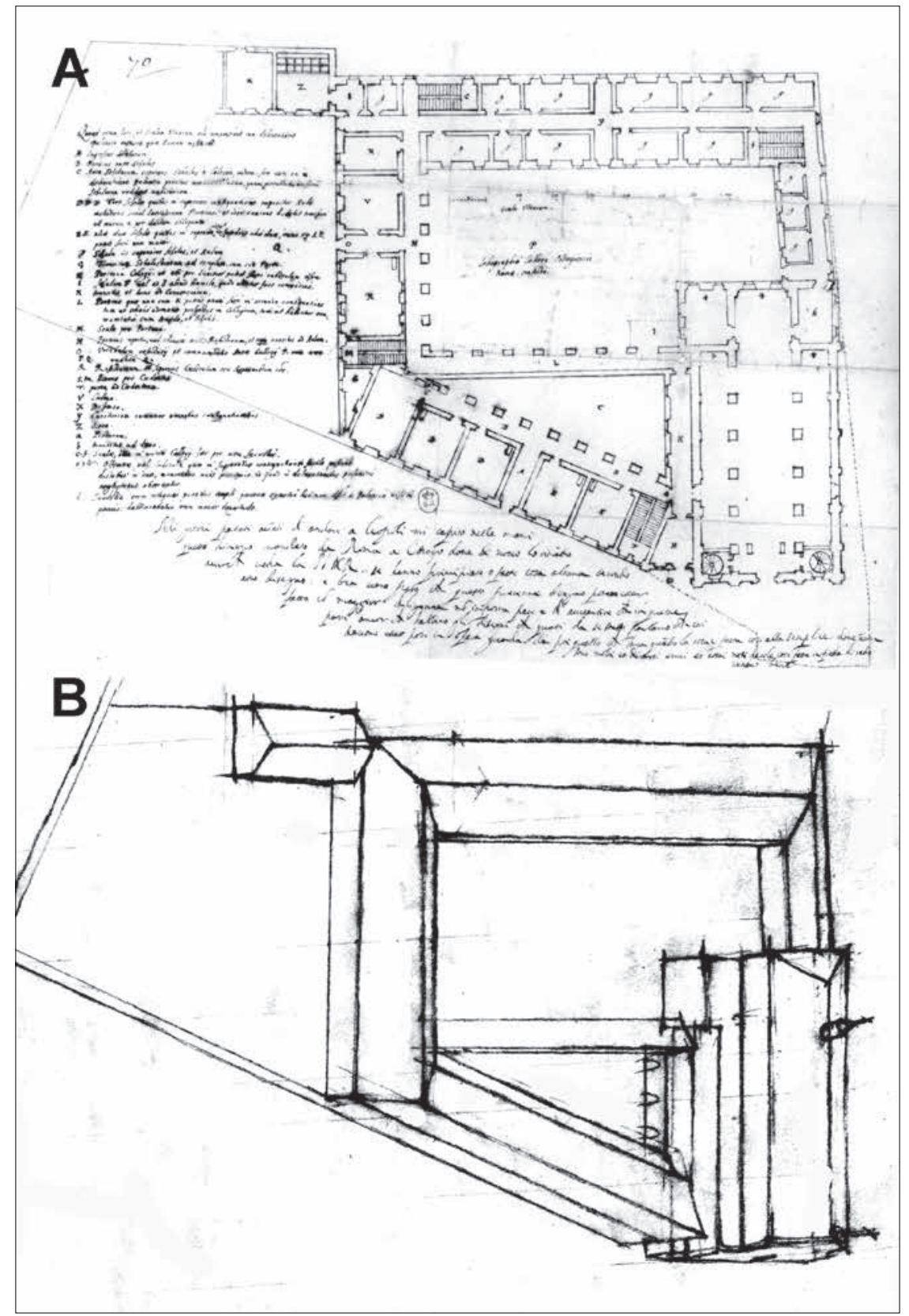

Рис. 1. Острозький єзуїтський колегіум.

Перший нереалізований проектний варіант:

A-архівний оригінал проектного плану. Арх. К. Грінбертер (?).

В - тривимірна гіпотетична візуалізачія проектної ідеї.

Опрацювання автора 


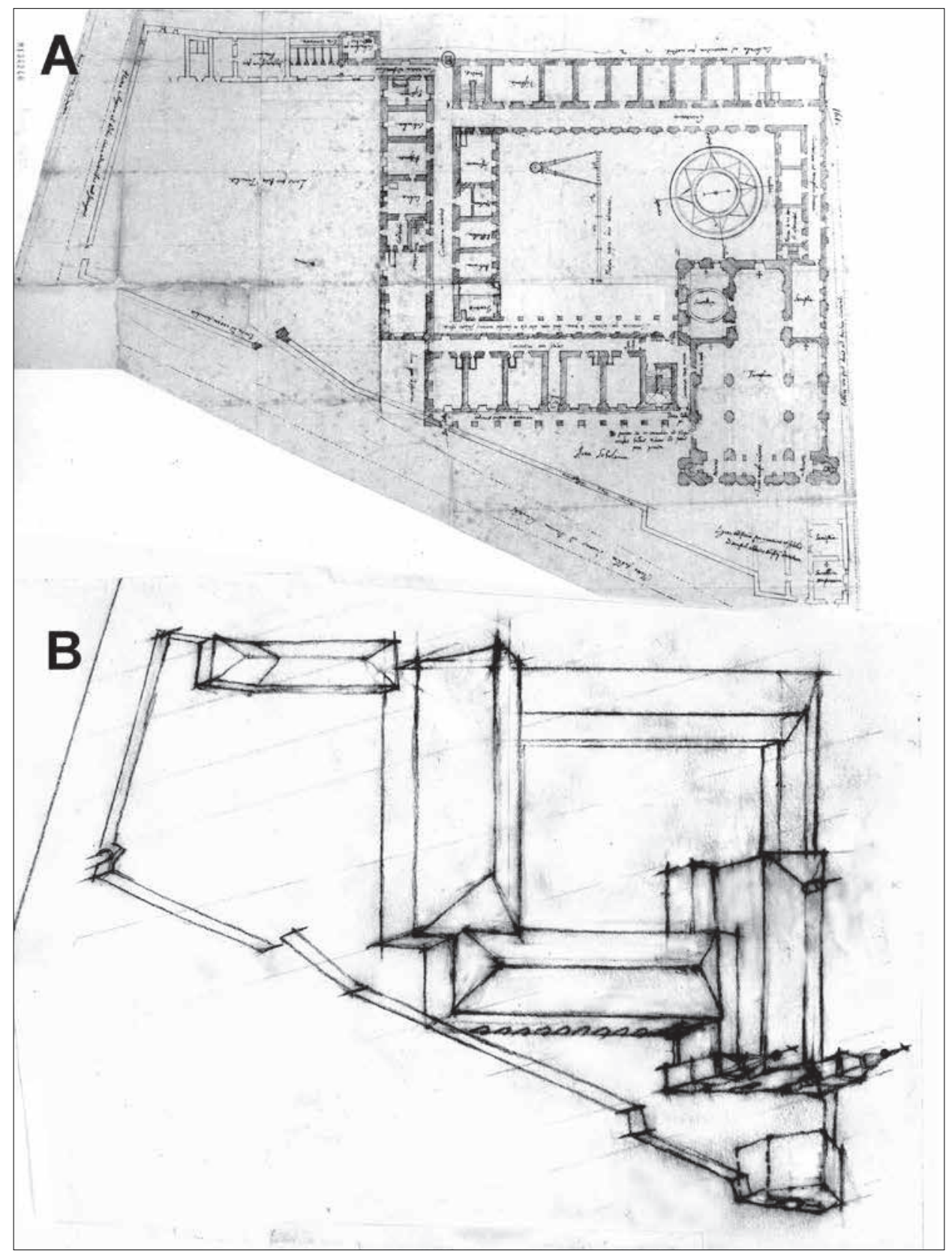

Рис. 2. Острозький єзуїтський колетіум.

Другий проектний варіант:

$A$ - архівний оригінал проектного плану. Арх. С. Браун (?).

$B$ - тривимірна гіпотетична візуалізачія проектної ідеї.

Опращювання автора 
частина території на ньому мала потужну огорожу, північний відрізок якої співпадав з міським оборонним муром, а безпосередньо за ним знаходився рів, наповнений водою від русла Вілії. Таким чином, оборонна функція зовнішнього кордону видавалася проектанту (і замовниці, очевидно, також) достатньо важливою.

На відміну від першого варіанту, цей проект мав виразніший архітектурний кшталт храму з розвиненою пластикою головного фасаду (рис. 2B). Власне, за цим варіантом, очевидно, і були розпочаті будівельні роботи. Оскільки на цьому плані перед головним входом до майбутнього костелу відтворено ще й фрагмент існуючої резиденції (рис. 3), гіпотетично можна пов'язати його створення 3 іменем світського архітектора Себастіана Брауна. Під наглядом саме цього фахівця реалізовувався початковий етап зведення комплексу. Зауважимо, що аналізований кресленик містить фіксацію тієї першої, досить скромної єзуїтської резиденції, яка була споруджена Анною-Алоїзою поблизу північно-східного кута ринкової площі невдовзі після появи єзуїтів в Острозі ${ }^{27}$. В одному з приміщень цієї будівлі позначено

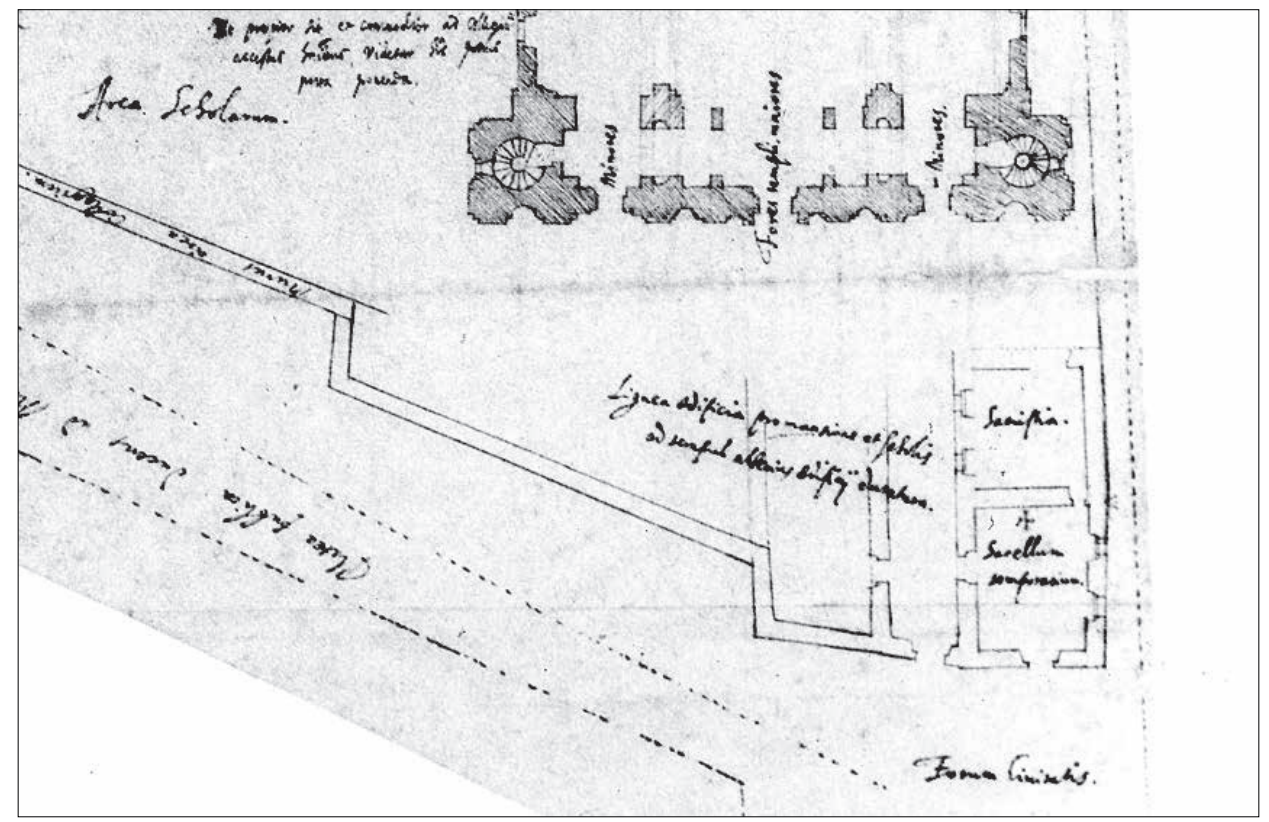

Рис. 3. Острозький єзуїтський колетіум. Другий проектний варіант. Арх. С. Браун (?). Фрагмент

В складі паризької колекції знаходиться також план другого поверху цього проектного варіанту з невеликими відмінностями в габаритах і конструктивних елементах в порівнянні 3 планом першого поверху. Ibidem. - P. 343 (Hd-4, 163).

${ }^{27}$ Zatęski S. Jezuici w Polsce. - Lwów, 1905. - T. 4, cz. 3. - S. 1251-1252. 
невелику каплицю. Відзначається також, що перший ії поверх був мурованим, а другий - дерев'яним.

Третій проектний варіант (рис. 4А), який, очевидно, безпосередньо передував початку роботи Джакомо Бріано в Острозі, датований 8 серпня 1629 року і засвідчений апробацією (погодженням) Помпіліо Ламбертенгі, візитатором Малопольської і Литовської провінцій Товариства Ісуса ${ }^{28}$. Головні його відмінності у порівнянні з попередніми проектами такі: на плані відсутня (фактично ліквідована?) будівля першої резиденції; зменшена вільна територія в північній частині колегіуму на користь забудови; внутрішній дворовий простір поділений на три фунціональні зони; до внутрішньої сторони міського муру допасовано дві баштоподібні споруди, певне з оборонними функціями. 3 архітектурних новацій звертають на себе увагу: більш виразне акцентування двох симетричних веж на головному фасаді, поява трансепту поряд 3 вівтарною частиною, істотне видовження нав костелу за рахунок додавання двох поперечних прясел (рис. 3В). Тобто зовнішній вигляд костелу у порівнянні з попередніми проектами набув у цьому варіанті більш монументальних рис.

Острозькі «прелюдії» архітектора. В листі від 21 січня 1630 року, адресованому орденському генералу Муціо Віттелескі, фундаторка повідомила про свою стурбованість станом будівництва. "Підземний костел в моїй дідичній маєтності в Острозі вже зведено, за благословенням Божим та Вашої Еміненці з'явилися також ознаки, хоч і невеликі, майбутнього колегіуму. Але оскільки у храмі проступило кілька тріщин, і немалих, побоююся, що коли зросте вага самих стін, склепінь та даху, тріщини тільки збільшаться, а разом 3 тим - і шкода значна для будівлі. Ще можна вчасно тому запобігти, якщо буде воля Вашої Еміненції відрядити того братчика італійця, котрий фундамент луцького костелу без жодної тріщини виставив" 29. Як випливає 3 прохання А.-А. Ходкевич, вона тримала будівництво під власним контролем і продемонструвала у цьому зверненні достатню обізнаність 3 технологією будівництва. Слова фундаторки були почуті, і незабаром «братчик італієць» (тобто єзуїт Джакомо Бріано) отримав розпорядження збиратися в далеку дорогу.

Першочерговим завданням майстра, що прибув на розпочате будівництво, мало бути усунення конструктивних вад, зумовлених незадовільними геологічними умовами земельної ділянки і хибами попередників. Генерал підтримав прохання фундаторки про відрядження Бріано невипадково, адже архітектор вже мав поважний досвід, працюючи раніше на єзуїтських новобудовах у Львові, Луцьку, інших містах тогочасної Речі Посполитої.

${ }^{28}$ Vallery-Radot $J$. Le recueil de plans d'édifices de la Compagnie de Jésus... - P. 343-344 (Hd-4, 162).

${ }^{29}$ Цит. за: Paszenda J. Biografia architekta Giacomo Briano... - S. 14. 


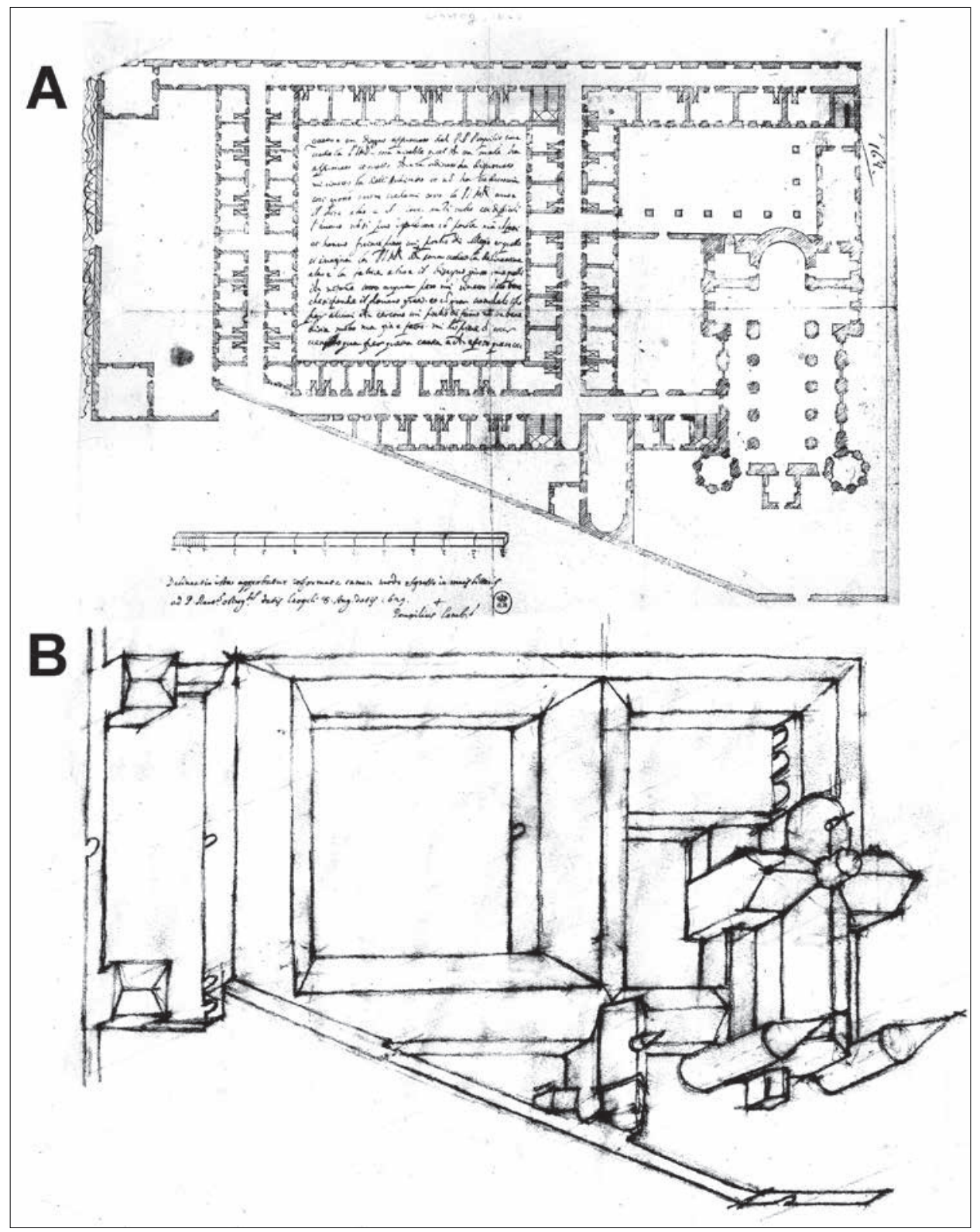

Рис. 4. Острозький єзуїтський колегіум. Третій проектний варіант: $A$ - архівний оригінал проектного плану з анотацією та підписом візитатора Товариства П. Ламбертенгі від 8 серпня 1629 р. Арх. С. Браун (?). Пізніші ремарки - Д. Бріано.

B- тривимірна гіпотетична візуалізачія проектної ідеї.

Опрацювання автора 
Про творче обдарування і навіть професійну самовпевненість Джакомо Бріано свідчить його звернення в 1611 році до очільника єзуїтів Клавдія Аквавіви 3 проханням дозволити йому «коментувати найславніших майстрів» на архітектурні теми ${ }^{30}$. Прохання було відхилене $з$ порадою зайнятися ліпше практичною діяльністю на будівництві єзуїтських осель ${ }^{31}$. Лише в останні роки життя він частково все-таки реалізував свої теоретичні амбіціiі, оправив в шкіру архітектурні альбоми зі своїми рисунками та кресленнями, і навіть організував їх виставку в бібліотеці Колегіi Романо ${ }^{32}$ в Римі. Орденський генерал оцінив їі як таку, що «дає фахівцям з архітектури добру можливість наслідувати його приклад» ${ }^{33}$.

До Острога Д. Бріано прибув у вересні 1630 року з рекомендацією генерала якомога менше вдаватися до трудомістких перебудов та економити на видатках. На місці архітектор дійшов висновку, що всі попередні проекти грунтувалися на неточних вимірах земельної ділянки, наданої фундаторкою, через що запроектовані раніше споруди не вписувалися в ії межі. Численні ремарки Д. Бріано на вищезгаданих проектах засвідчують, що він не лише отримав ці проектні версії у своє розпорядження, а й сформулював критичну оцінку їхнього змісту. Водночас, втілити власні творчі задуми Бріано було складно через наявність вже виконаних фундаментів та частини цоколя, конструктивні вади, а ще через постійні дискусії з фундаторкою щодо змісту подальшого проектування. Та найгостріше стояло питання про розширення земельної ділянки, на чому наполягав архітектор. Анна-Алоїза пообіцяла виконати його прохання. Відтак Бріано склав ще два обміри, в яких було показано наявний територіальний ресурс і висловлено пропозиції щодо його нарощення для подальших проектних робіт. Пізніші топографічні плани Острога засвідчують, що істотного збільшення площі комплексу так і не відбулося.

У збірці Національної бібліотеки Франції зберігаються три кресленика земельної ділянки, виконані Д. Бріано. Перший - фіксаційний з реальними межами цієї території, два інші вказували на можливі варіанти іiі розширення.

На першому плані ("prima delineatio") 34 докладно окреслено фактичні кордони раніше сформованої ділянки з маркуванням усіх важливих опорних пунктів по її периметру (рис. 5). Очевидно, прискіпливість у визначенні кордонів була зумовлена не лише дефіцитом територіального ресурсу, але й невдоволенням навколишніх мешканців, переважно євреїв, які явно не хо-

\footnotetext{
${ }^{30}$ Paszenda J. Biografia architekta Giacomo Briano... - S. $14 .$.

${ }^{31}$ Bösel R. Typus und Tradition in der Baukultur... - S. 246.

${ }^{32}$ Collegium Romano - папський навчальний заклад єзуїтів, відкритий в Римі у 1584 році. Знаходився він у будівлі, спеціально спорудженій за проектом флорентійського архітектора Бартоломео Амманатті.

${ }^{33}$ Цит. за: Bösel R. Typus und Tradition in der Baukultur... - S. 246.

${ }^{34}$ Vallery-Radot J. Le recueil de plans d'édifices de la Compagnie de Jésus... - P. 344 (Hd-4d, 200).
} 


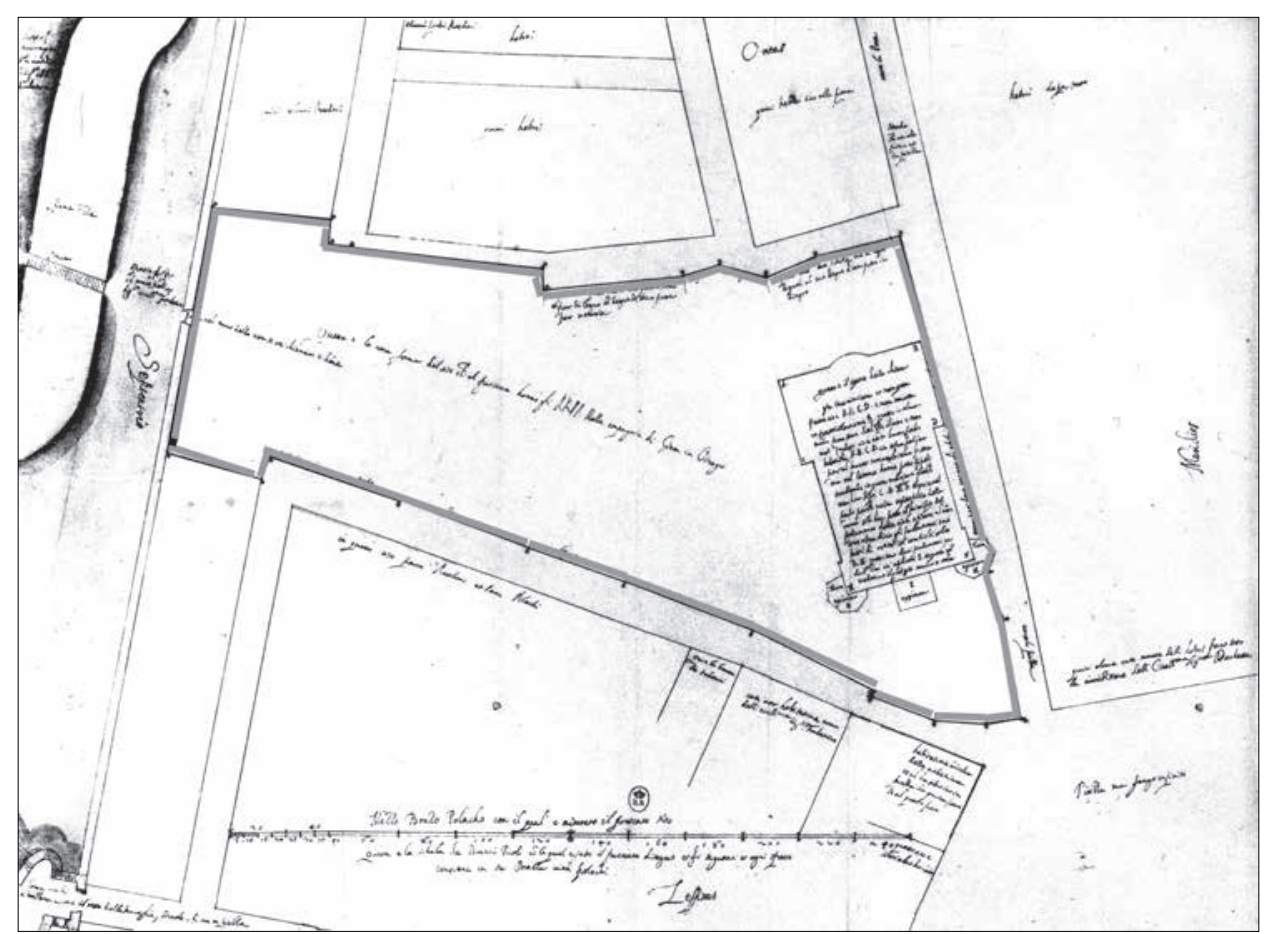

Рис. 5. Фіксаційний план земельної ділянки, відведеної під будівництво фундаторкою. Арх. Д. Бріано

тіли поступатися своїм «життєвим простором», сформованим історично i, очевидно, не без згоди попередніх власників міста. Справді, територіальний дефіцит на кресленні легко простежується, особливо зважаючи на значні габарити храму, що вже почав зводитися. Явно більших площ потребував також майбутній колегіум, для розміщення якого наявна ділянка була замалою. Північна іiі частина виглядала надто вузькою, затиснутою дворами острозьких міщан. Недоліком ділянки був також доволі незручний підхід до неї з північно-східного кута ринкової площі, що в майбутньому заважало б розкриттю головного фасаду костелу в напрямку до осердя міста, створюючи недоречні візуальні перешкоди. До всього сказаного слід додати, що східний кордон ділянки мав декілька нерегулярних заломів, до яких примикала невелика вулиця, а це також виглядало небажаним чинником.

Таким чином, на першому кресленні зазначені абрис уже збудованих підмурків костелу, кордони ділянки з опорними межовими знаками, частина ринкової площі (справа внизу), план Татарської брами (зліва внизу) і фрагмент міського оборонного муру 3 «фуртою». Остання вела до містка через річку Вілію, яка протікала вздовж міської стіни на відстані усього кільканадцяти метрів від неї. 


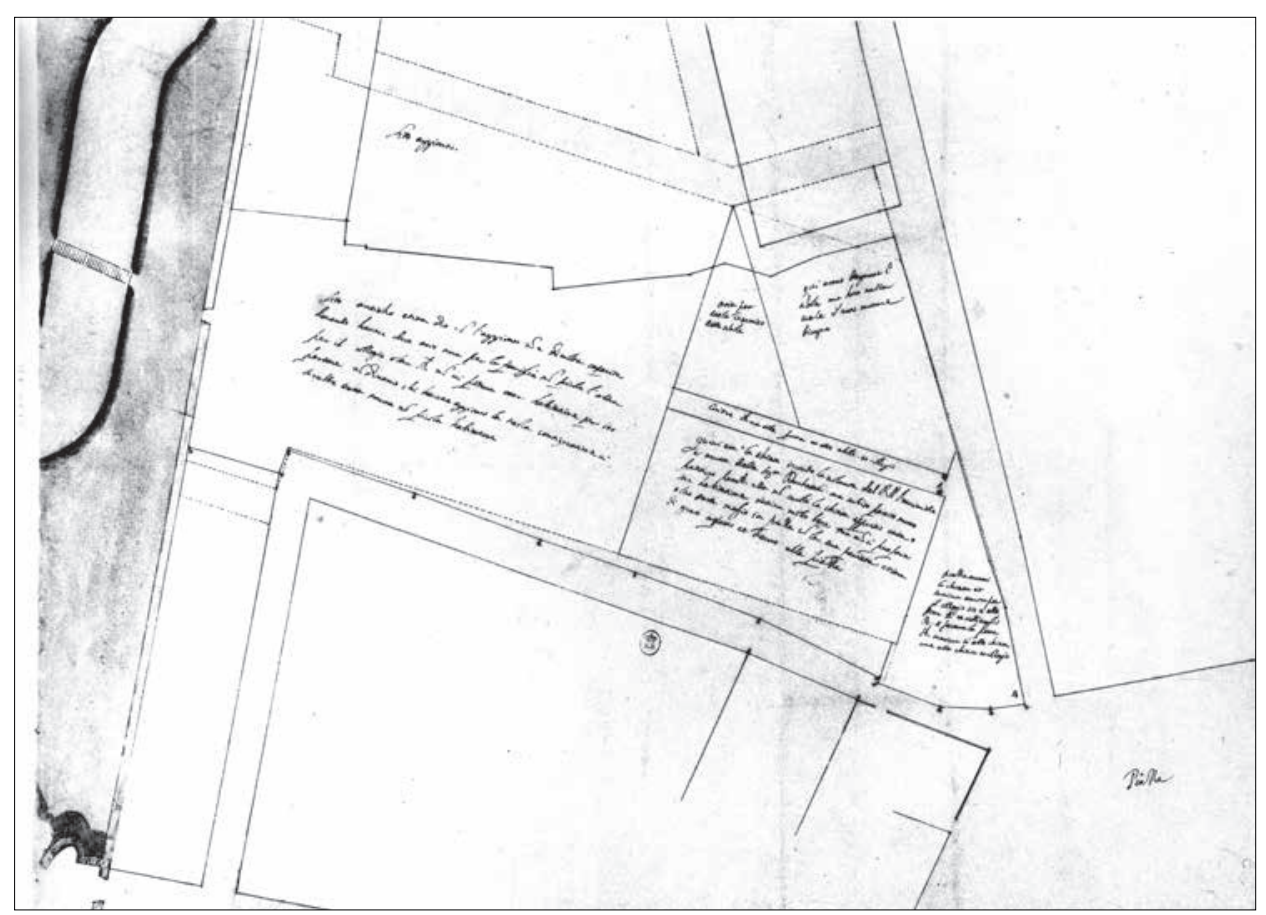

Рис. 6. Фіксаиійно-проектний план земельної ділянки, відведеної під будівництво фундаторкою (варіант 1). Арх. Д. Бріано

Розуміючи складність завдання побудувати комплекс споруд на такій незручній ділянці, Бріано підготував іще один земельний план ${ }^{35}$ (рис. 6). Територія під майбутнє будівництво на ньому збільшена, за приблизними обрахунками, майже в півтора рази. Східні межі ділянки тут розширені і вирівняні в одну лінію, зіперту по всій своїй довжині на новопрокладену вулицю. В разі затвердження змін архітектор мав би більше можливостей для пошуку оптимального розпланувального рішення усього єзуїтського комплексу, в якому виразно проглядалося кілька окремих зон для розміщення костелу, колегіуму, конвікту, а також невеликої аванплощі перед зовнішнім кутом міського ринку.

Просторове затиснення щойно згаданої аванплощі міщанською забудовою з обох боків зумовило появу третього варіанту територіального зонування, який передбачав подальше розширення ділянки майже вдвічі ${ }^{36}$ (рис. 7). Це розширення вело до ще більш інвазійного втручання в існуючу міську інфраструктуру, головно в ту іiі частину, яка належала єврейській громаді $i^{37}$.

\footnotetext{
${ }^{35}$ Vallery-Radot $J$. Le recueil de plans d'édifices de la Compagnie de Jésus... - P. 344 (Hd-4d, 201).

${ }^{36}$ Ibidem. - P. 344 (Hd-4, 202).

37 Показово, що в привілеї на будівництво великої мурованої синагоги Магарша Анна-Алоїза Ходкевич заборонила будувати іiі вищою за християнські храми. Див.:
} 


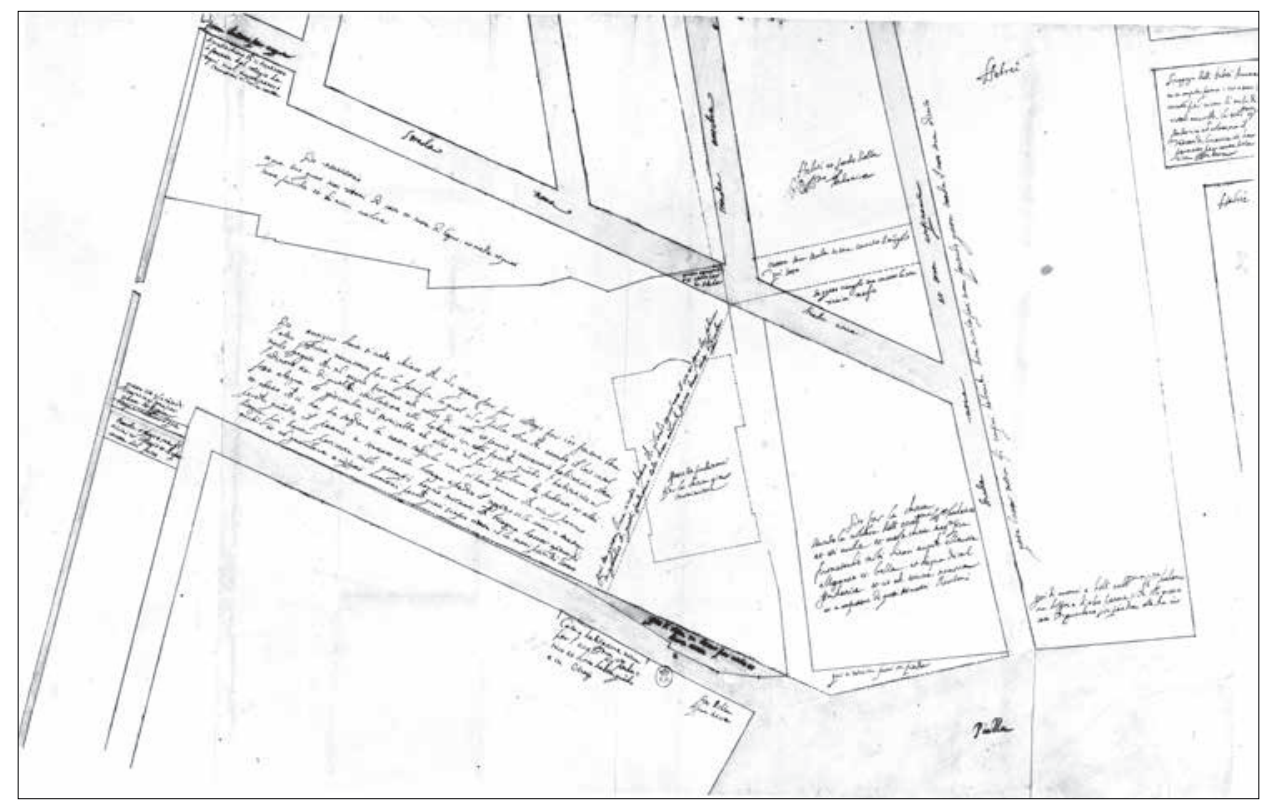

Рис. 7. Фіксаційно-проектний план земельної ділянки, відведеної під будівнищтво (варіант 2). Арх. Д. Бріано

Фактично пропонувалося вилучення на користь Товариства ще однієї частини міської території. Очевидно, під тиском невдоволених городян, Бріано дещо звужує ширину ділянки, але водночас подовжує іiі, пропонуючи масштабну «інтервенцію» в південному напрямку з виходом безпосередньо на східну сторону ринкової площі. Звичайно, така просторова експансія у разі iii реалізації давала б гарний шанс розмістити головний фасад єзуїтського костелу безпосередньо по східному фронту цієї площі в якості домінантного композиційного об'єкту. Тобто фактично передбачалася експропріація чималої частини територій єврейської громади, яка у близькому сусідстві на той час зводила монументальну муровану синагогу ${ }^{38}$.

Цілком імовірно, що цими трьома топографічними планами Д. Бріано не обмежився й надалі шукав варіанти використання територіального ресурсу. Без певності у вирішенні земельного питання його подальша робота була би просто неможливою.

Однак крім земельного питання не менш гостро стояла проблема творчої комунікації архітектора із фундаторкою орденської оселі. Джакомо Бріано доводилося враховувати не лише обмежені просторові границі ділянки, від-

Kravtsov S.R., Levin V. Synagogues in Ukraine. Volhynia. - Jerusalem, 2017. - Vol. 2. - P. 496.

${ }^{38}$ Про гострі майнові суперечки новоприбулих єзуїтів та єврейської громади у травні 1626 року повідомляв белзького воєводу Рафала Лещинського князь Олександр Заславський. Див.: Александрович B. Мистецькі клопоти князя Олександра Заславського // Український археографічний щорічник. - Київ, 2010. - Вип. 15. - С. 193-194. 
веденої для будівництва, а й постійно узгоджувати з патронесою свої архітектурні задуми. Як виявилося, в особі Анни-Алоїзи він отримав не просто заможного мецената, а й достатньо самостійного в архітектурних уподобаннях замовника, що прагнув побудувати в своєму родовому гнізді величну католицьку святиню разом із навчальним закладом. Як виглядає, пані Ходкевичева послідовно демонструвала італійцю власні архітектурні смаки і явно не бажала беззастережно сприймати його творчі задуми.

Тут, дещо випереджаючи подальший виклад, доречно констатувати безуспішний фінал творчої праці архітектора, зафіксований ним самим у пізніших спогадах про-перебування в Острозі «поміж русинів і схизматиків». Особливо виразною ця оцінка виглядає на тлі згадки про авторитет знаменитого античного архітектора-теоретика Вітрувія ${ }^{39}$ : «що стосується цієї пані, а також деяких наших отців, то досі, з Божою ласкою, не вдалося знайти форми [колегіуму - П.Р.], котра би їй сподобалася, і одному Богу відомо, коли це трапиться... А може і взагалі не існує рисувальника, котрий мав би стільки терпіння, щоб зуміти задовольнити найсвітлішу пані княжну... Тут кожен може собі зауважити, що не належить жінкам керувати мужчинами... Отже, нехай буде всім відомо і оголошено..., що я, Джакомо Бріано, моденець, єзуїт, раніше був на службі в багатьох впливових володарів і князів, а тепер змушений перебувати у смутку, маючи служити самовпевненій княжні, яку, використавши вже три пакунки паперу, не можу задовольнити, і якщо найсвітліша пані княжна фундаторка знову невдоволена вже дванадцятим [рисунком - П.Р.], тоді нехай сюди прибуде Вітрувій з усіма своїми послідовниками» ${ }^{40}$. Півторарічна праця майстра результатів так і не дала, $\mathrm{i}$ після того, як останній його проект також було відхилено, Бріано в розпачі повернувся на батьківщину.

Tворчі версії архітектора. Після докладного вивчення топографічних характеристик земельної ділянки і досягнення консенсусу з фундаторкою стосовно можливостей іiі збільшення Д. Бріано розпочав творчий пошук архітектурного образу для майбутнього комплексу Товариства Ісуса. Засадничим, вихідним етапом такого пошуку були генеральні плани ділянки 3 розміщенням на них основних будівель, котрі, в свою чергу, мали були достатньо деталізованими, з показом усіх приміщень.

Оцінюючи “острозьку спадщину” Бріано, доводиться констатувати, що не всі його 12 проектних варіантів дійшли до нашого часу, хоча відомо, в

${ }^{39}$ Покликання на авторитет Вітрувія - знаменитого античного майстра, автора першого архітектурного трактату «Десять книг про зодчество» - свідчить не лише про знання Д. Бріано архітектурної історії. Воно також характеризує рівень компетентності та професійних вимог до майстра з боку Анни-Алоїзи.

${ }^{40}$ Цит. за: Betlej A. "Niech przyjdzie tu Witruwiusz wraz ze swoimi następcami”... - S. 193. 3 контексту цієї заяви непрямо випливає, що дванадцятий варіант проекту Д. Бріано виявився останнім. 
останні роки життя архітектор подбав про створення колекції своїх праць, зібравши їх в спеціальні альбоми ${ }^{41}$. На жаль, після смерті єзуїта ця графіка розійшлася по різних державних і приватних колекціях. Найбільше робіт зосереджено у фондах Національної бібліотеки Франції. Їх острозький сегмент представлений переважно проектними генеральними планами, які демонструють конкретні варіанти пристосування майбутнього єзуїтського колегіуму до локальної топографії.

На сьогоднішній день нам відомо 5 таких планів 3 детальним розподілом окремих корпусів та приміщень. 3 певними застереженнями, однак вони дають можливість гіпотетичного відтворення третього, висотного виміру, а отже і гіпотетичної об'ємно-просторової характеристики архітектурних ідей Д. Бріано. Він пропонує різні способи просторової локалізації храмової будівлі, варіанти їі розпланування, а також достатньо деталізовані креслення пов'язаних між собою і допасованих до костелу приміщень дидактичного, житлового та господарського призначення. Ці документи наочно демонструють авторську логіку проектного пошуку в контексті міського середовища. Вона враховувала кордони земельної ділянки, функціональні потреби колегіуму i, звісно, його візуальні зв' язки з існуючим міським середовищем.

Залишається, щоправда, відкритим питання послідовності виконання цих проектних планів, оскільки відсутня їх хронологічна атрибуція. До того ж, не забуваймо, уціліло лише п'ять із щонайменше дванадцяти проектних версій. Тому запропонована нижче послідовність носить умовний характер і не претендує на фактичну відповідність реаліям минулого.

Почнемо 3 проекту, який, можливо, не був першим (рис. 8А), однак за своїми просторовими параметрами і розпланувальною конфігурацією є найближчим до варіанту, реалізованого в кінцевому підсумку (рис. 18). Здається, не випадково, Ж. Валері-Радо розмістив його на останньому місці острозького проектного списку ${ }^{42}$. 3 точки зору пристосування до наявної ділянки виглядає він достатньо прагматичним. В проекті виокремлено три внутрішні дворові зони зі шкільною, колегіальною та господарською функціями. Серед усіх подальших планів його вирізняє надмірна гіперболізація прямокутного двору колегіуму з використанням дуже популярних в Італії, проте нехарактерних для волинського клімату колонад атріумного типу. Проектне вирішення самого костелу характеризується хрещато-баневим типом з коротким трансептом і неглибокою вівтарною частиною. Для такого розпланування характерними є підвищена центральна нава, а над середохрестям - купольний верх. Звертають на себе увагу також підмурки вежі,

${ }^{41}$ Paszenda J. Biografia architekta Giacomo Briano... - S. 16.

42 Vallery-Radot J. Le recueil de plans d'édifices de la Compagnie de Jésus... - P. 346 (Hd-4d, 18). Підпис на звороті: "Delineatio collegii Ostrogi[ensis] et Templi ac Scolaru[m] facta per Jacobum Brianum...”. 


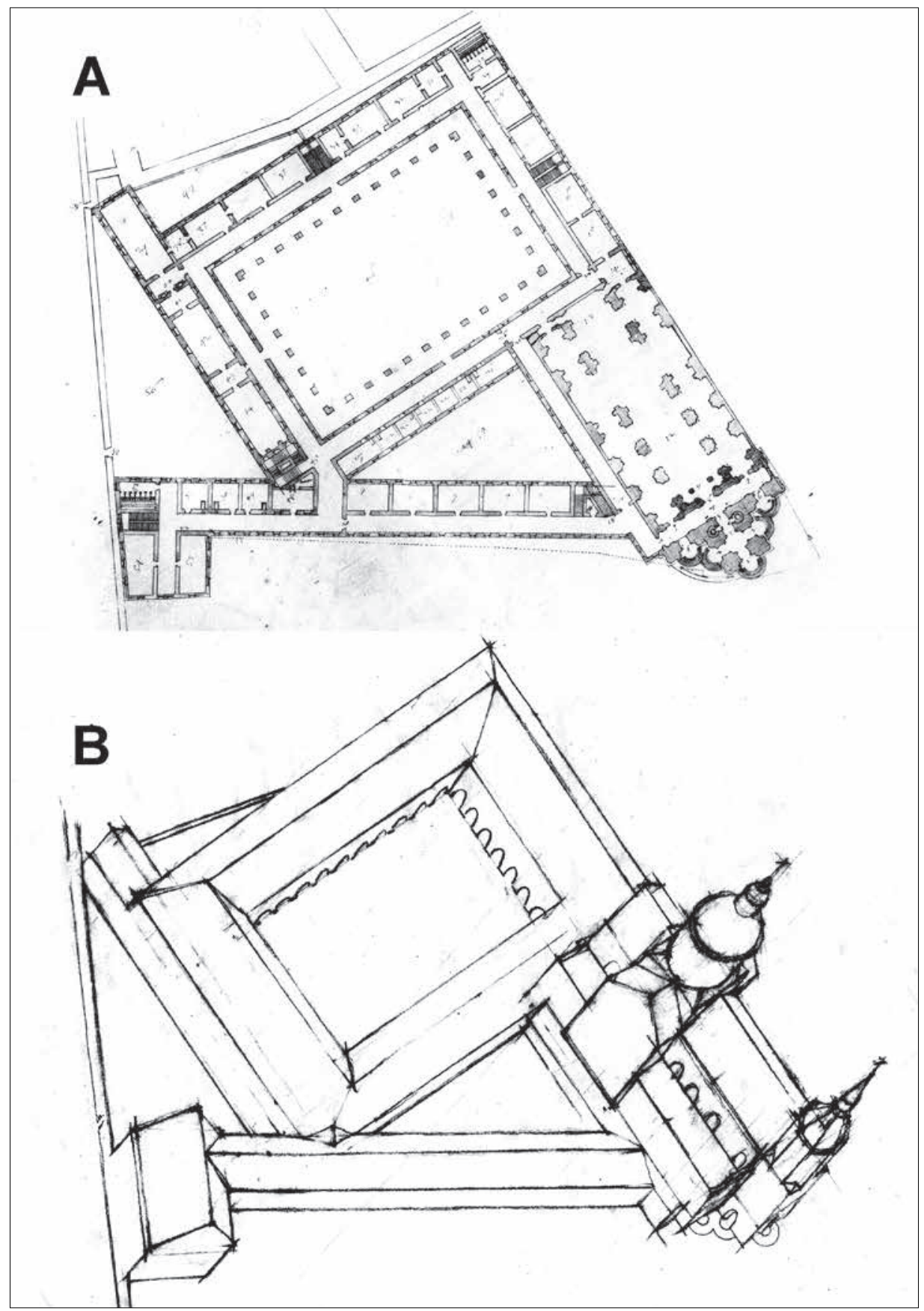

Рис. 8. А. Проектний план Острозького єзуїтського колегіуму (варіант 1). Арх. Д. Бріано.

В. Гіпотетична тривимірна візуалізація. Рисунок автора 
допасованої спереду до головного входу. Сама вежа, очевидно, мала взяти на себе роль висотного акценту в загальній храмовій композиції (рис. 8В).

Другим проектним варіантом умовно визнаємо той, що демонструє спробу організувати розпланувальну композицію видовженого (лінійного) типу ${ }^{43}$ (рис. 9А). Така схема мала переваги простішого пристосування до сусідньої забудови і виходу головним фасадом на ринкову площу. Серед потенційних ускладнень - суміщення внутрішніх колегіальних функцій (навчальної, житлової та господарської) внаслідок небажаного перетинання шляхів внутрішньої комунікації. Фактично до такого великого закладу (окрім входу до костелу) залишався лише один доступ - через вхід зліва від храму. При цьому сам костел Д. Бріано запроектував з більш виразним трансептом і $з$ доповненням головного вівтаря двома бічними абсидами. На нульовому рівні цікавим засобом комунікації виглядають дві бічні галереї, які полегшували зв’язки і урізноманітнювали внутрішній простір разом з бічними вівтарями. Судячи з плану, істотно змінювалася і фасадна композиція внаслідок появи двох симетричних веж, що загалом відповідало пізньобароковим манерам. Над перехрестям трансепту та головної нави, швидше за все, мав височіти купол на круглому або, можливо, овальному плані (рис. 9В).

Третій проектний варіант за напрямком «північ - південь» виглядає значно коротшим ніж попередній (рис. 10А). До його появи могла призвести відмова архітектора від ідеї вийти храмовим фасадом на східну сторону ринкової площі. Водночас, тут маємо цікаву пропозицію створення перед головним фасадом костелу невеликої атріумної площі з парадним входом, яка мала би відігравати роль урочистої аванзони. Власне, через цей атріум мав здійснюватися доступ одночасно і до костелу, і до колегіуму. Звертає на себе увагу ідея забудови усієї земельної ділянки, внаслідок чого фактично утворювався стіновий мур по усьому периметру об'єкту. I навіть північна сторона, обмежена загальноміським муром, мала б отримати трапецієподібну в плані прибудову (і також, очевидно, надбудову) з автономним входом і півциркульними сходами. Наявність таких сходів засвідчувала появу вищих рівнів і особливу роль цього комунікаційного вузла. Отже, в ширшому сенсі, третій варіант може означати альтернативу невдалим спробам прилучити до колегіуму додаткові міські території. Разом з тим, двоярусний атріум перед головним входом давав можливість роздільного доступу до костелу (верхній ярус) і цокольного рівня (крипти). Сам храм, за планувальним вирішенням, отримував у цьому варіанті двобаштову композицію чільного фасаду, а також, імовірно, однобаневий верх над середохрестям нави та трансепту (рис. $10 \mathrm{~B})$.

Четвертий варіант (рис. 11А) в колегіальній частині дуже подібний до попереднього, окрім незначних змін в розташуванні сходів та в розмірах

\footnotetext{
${ }^{43}$ Vallery-Radot J. Le recueil de plans d'édifices de la Compagnie de Jésus... - P. 345 (Hd-4d, 196).
} 


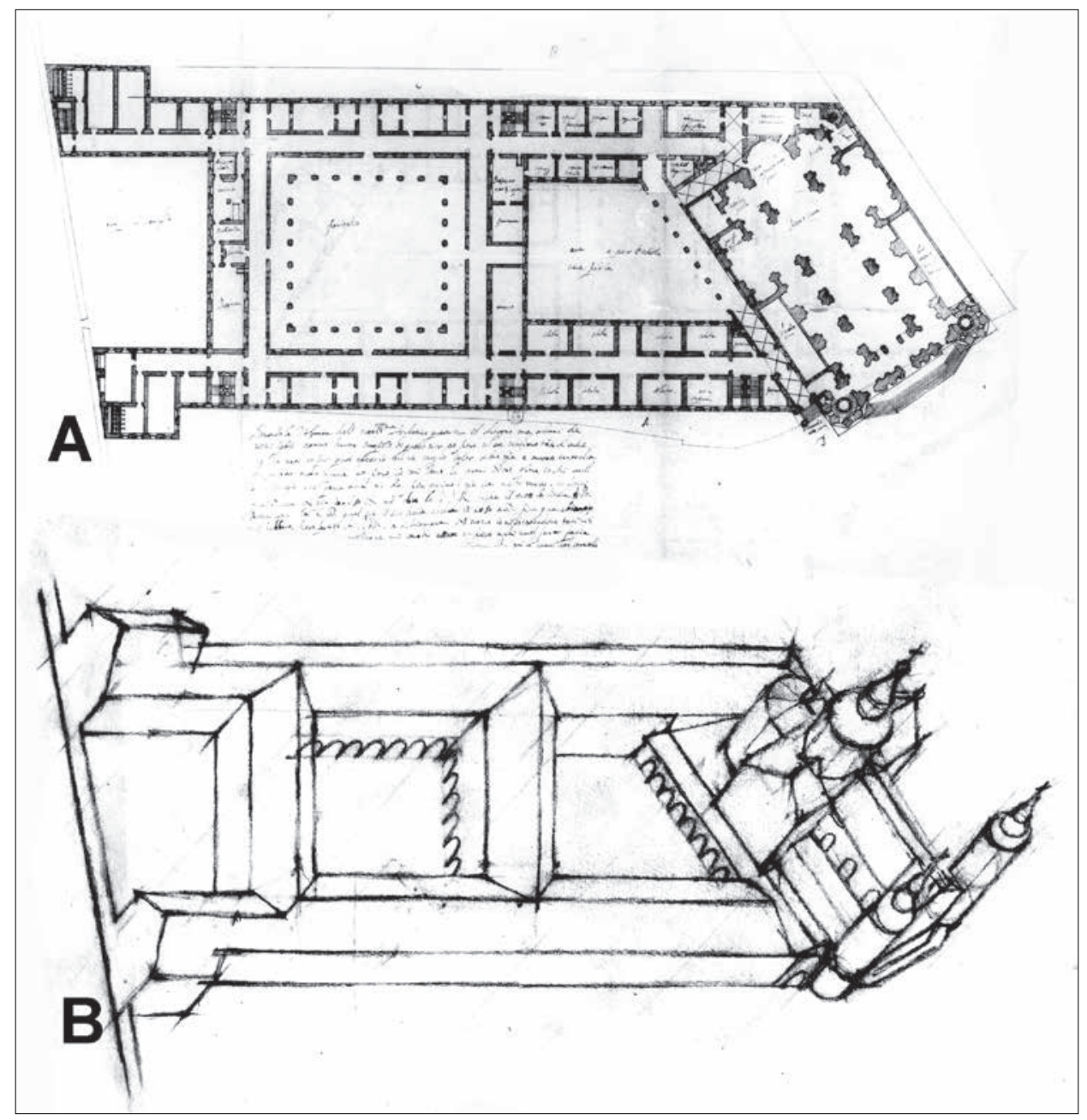

Рис. 9. А. Проектний план Острозького єзуїтського колегіуму (варіант 2). Арх. Д. Бріано.

В. Гіпотетична тривимірна візуалізаиія. Рисунок автора

приміщень. Суттєві відмінності бачимо, натомість, в розпланувальному вирішенні храмової будівлі. Можна припустити, що на певному етапі дискусій з фундаторкою Д. Бріано довелося звернути особливу увагу на горішню частину храмової композиції i, зокрема, такий важливий засіб архітектурного завершення сакральної будівлі, як бані. На кресленні вони чітко артикульовані у вигляді семи підкупольних кілець. До цієї семичастної композиції додавалася восьма домінанта - висока вежа над головним входом. В підсумку утворювався своєрідний стилістичний симбіоз двох архітектурних традицій візантійської східної та римо-католицької західної (рис. 11В). Перша тяжіла 


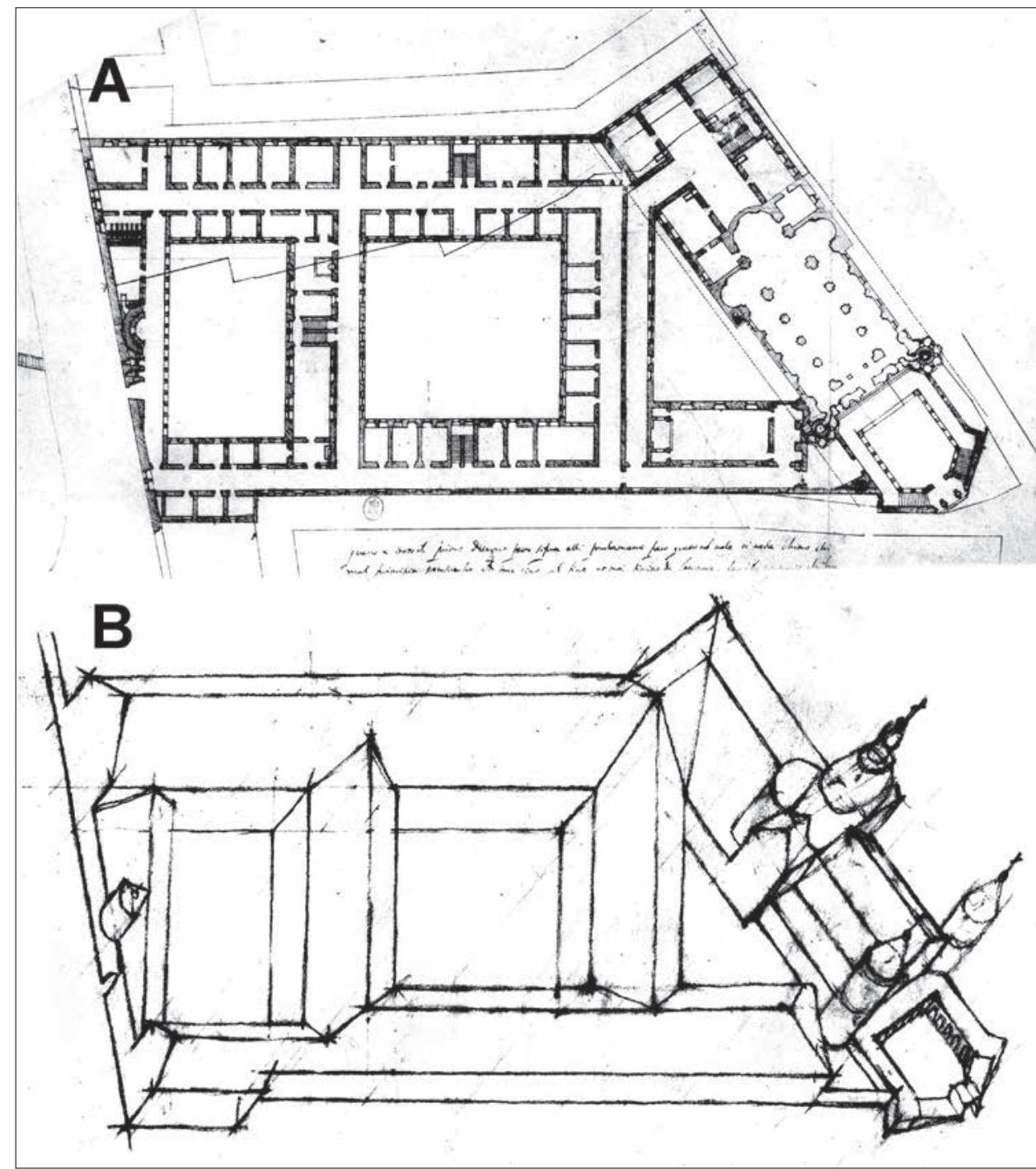

Рис. 10. А. Проектний план Острозького єзуїтського колегіуму (варіант 3). Арх. Д. Бріано.

В. Гіпотетична тривимірна візуалізація. Рисунок автора

до виразного центризму, друга - до видовженого, базилікального розпланування. Тут можна обережно припустити, що джерелом і натхненницею такого «симбіозного» підходу до формування храмової архітектурної стилістики була сама патронеса Анна-Алоїза Ходкевич, як фактичний носій двох сакральних архетипів, - східного (за традиціями предків) і західного (згідно зі своїм католицьким віровизнанням). 


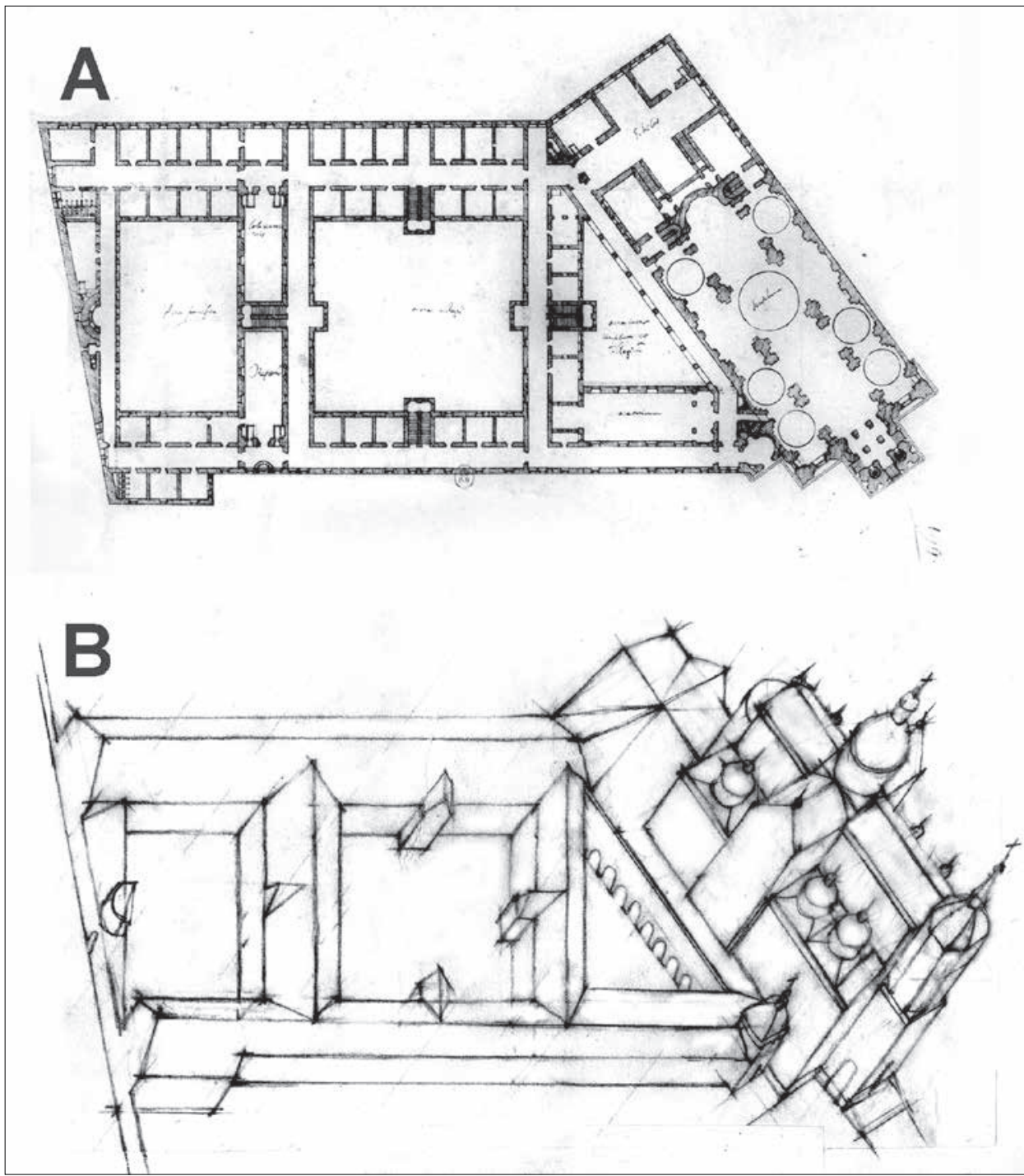

Рис. 11. А. Проектний план Острозького єзуїтського колегіуму (варіант 4). Арх. Д. Бріано.

В. Гіпотетична тривимірна візуалізачія. Рисунок автора

П'ятий варіант (рис. 12А) істотно вирізняється від вищезгаданих незвичною орієнтацією храмової будівлі. Ї̈̈ головна повздовжня вісь мала бути спрямована не так, як в усіх вищезгаданих храмах (паралельно до сучасної вул. Східної), а в напрямку західної стіни колегіуму, що сьогодні співпадає 3 лінією локальної вулички Волгіна. Для того, аби реалізувати задум, довелося б повністю розібрати вже виконані підмурки костелу та, частково, коле- 


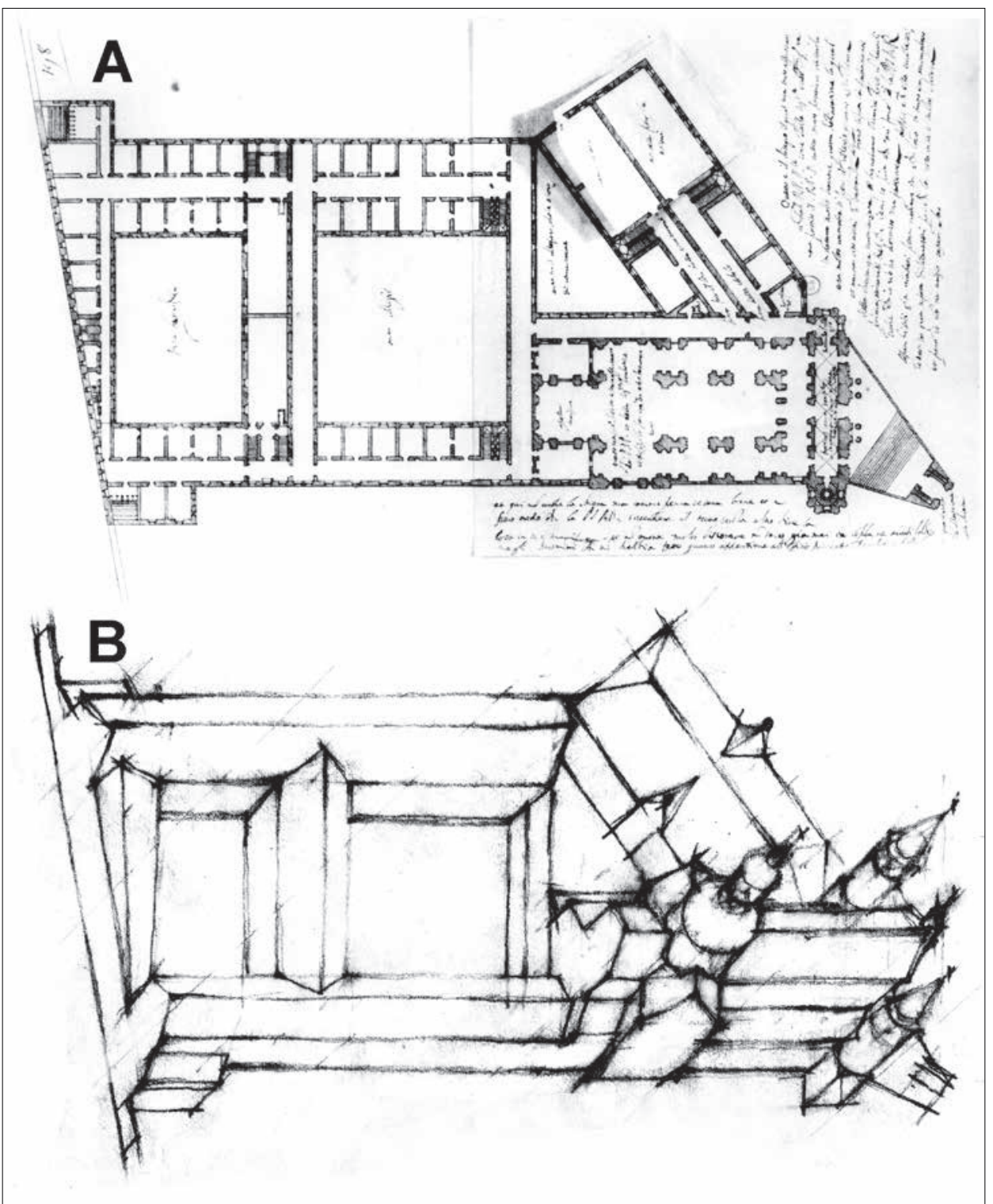

Рис. 12. А. Проектний план Острозького єзуїтського колетіуму (варіант 5). Арх. Д. Бріано.

B. Гіпотетична тривимірна візуалізація. Рисунок автора 
riуму, що було вкрай проблематичним. Таку оригінальну версію архітектор міг запропонувати передовсім з репрезентативних міркувань. На користь нашого здогаду свідчать нестандартно розташовані головні сходи до храму, південна сторона яких вирівнюється вздовж прилеглої вулиці, а головна вісь скеровується на ринкову площу. До бічного (східного) фасаду костелу передбачалося долучити декілька зальних приміщень на старих підмурках. Цікаво, що в анотації до проекту зафіксовано факт його затвердження провінціалом Товариства Ісуса. Втім, невдовзі рішення було скасоване ${ }^{44}$. Без сумніву, це сталося через конструктивні та технологічні ускладнення.

Слід наголосити на тому, що всі охарактеризовані вище проектні варіанти становлять меншу частину доробку, створеного архітектором в Острозі впродовж півтора року. Ще сім креслень віднайти не вдалося. Або вони досі зберігаються в архівах та приватних збірках, або просто фізично "зносилися" після того, як потрапили до рук наступників Бріано. Цілком вірогідно, що вони могли використати його напрацювання в своїй роботі.

В науковий обіг уведено ще ряд бріанівських креслень, пов'язаних 3 Острогом, які істотно доповнюють творчий спадок цього майстра в інших проектних «жанрах». Це декілька розрізів та фасадів, особлива цінність яких полягає в можливості ближчого, хоча і фрагментарного, ознайомлення з авторською архітектурною стилістикою.

В першу чергу варто відзначити повздовжній розріз по костелу разом 3 колегіумом, прибудованим до вівтарної частини храму (рис. 13). Цей документ зі збірки Дослідного інституту Жана-Поля Гетті був опублікований Анджеєм Бетлеєм 3 однозначною прив'язкою до Острога ${ }^{45}$. Співставлення

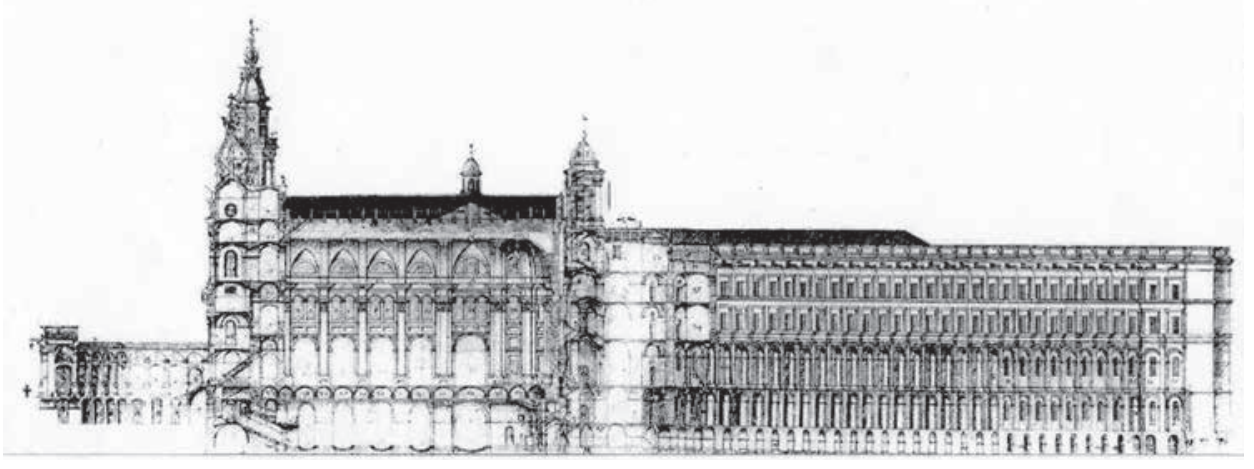

Рис. 13. Проектний повздовжній розріз костелу та частини фасаду Острозького єзуїтського колетіуму. Арх. Д. Бріано

${ }^{44}$ Vallery-Radot $J$. Le recueil de plans d'édifices de la Compagnie de Jésus... - P. 345.

${ }^{45}$ Betlej A. Appunti sui disegni del gesuita Giacomo Briano. - P. 21. Публікуючи креслення, автор статті повідомив про прикру втрату цього оригіналу за невідомих обставин. 
креслення 3 наведеними вище пропозиціями Бріано дозволяє визнати його таким, що за змістом відповідає одному з проектних планів паризької колекції (варіант 3). Підставою для такої атрибуції можна вважати характерну аванзону перед головним входом до храму й прикметне падіння рельєфу у східному напрямку, яке зумовило в процесі будівництва появу окремого, досить розвинутого цокольного поверху (крипти). На цьому кресленні звертає на себе увагу східний фрагмент колегіуму, прибудований до вівтарної частини костелу. Майже неймовірним, як на той час, можна вважати передбачення в цій гігантській будівлі аж шести поверхів (включно з цокольним рівнем). Навіть серед провідних католицьких центрів Європи важко віднайти більш монументальний архітектурний задум, а як для Острога, то він виглядає просто фантастично. Можливо, саме в схильності до архітектурної гігантоманії корінилися причини конфліктів майстра та замовниці?

Відомі ще два острозьких креслення Д. Бріано у вигляді поперечних розрізів храмової будівлі ${ }^{46}$ (рис. 14). Перший кресленик (зліва) - це розріз безпосередньо по осі рядового прясла, другий (справа) стосується площини, в яку потрапляють дві горішні бані над бічними навами. В нижній частині будівлі передбачалася доволі висока крипта 3 потужними склепіннями, котра, очевидно, стала наслідком відчутного падіння рельєфу на цій ділянці в східному напрямку. Падіння виявилося настільки суттєвим, що в цій частині крипти навіть стало можливим влаштувати віконні отвори в зовнішніх
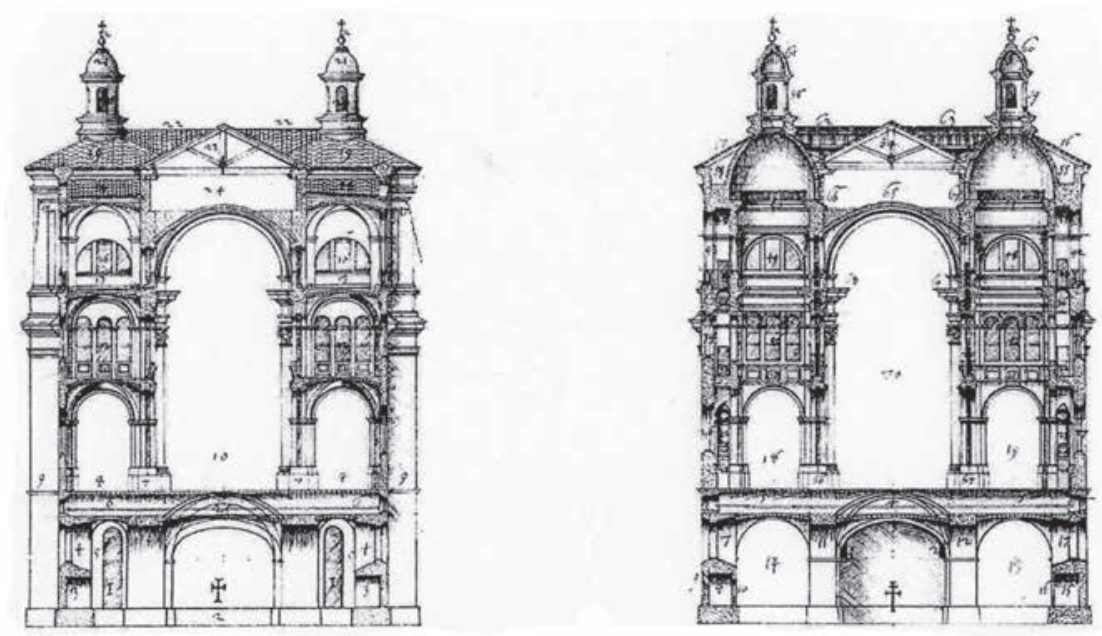

Рис. 14. Проектні поперечні розрізи костелу Острозького єзуїтського колетіуму: по рядовому пряслу (зліва); по пряслу з банями (справа). Арх. Д. Бріано

\footnotetext{
${ }^{46}$ Betlej $A$. "Niech przyjdzie tu Witruwiusz ze wszystkimi swoimi następcami”... - S.215, rys. 11.
} 
стінах. Посередині над криптою передбачалася висока головна нава, перекрита циліндричним склепінням. 3 обох ії сторін архітектор прагнув розмістити високі півколони коринфського ордеру, допасовані до несучих опор. Бічні нави запроектовано значно нижчими, що дозволило влаштувати над ними ярус обхідних галерей (емпор), з яких можна було не лише оглядати навколишні панорами, а й спостерігати за літургійними відправами в головній наві. На другому розрізі відтворено також внутрішній простір бань, які забезпечували додаткове горішнє освітлення. Загалом, на обох кресленнях спостерігається виразне ускладнення декоративного деталювання, - явно не на користь архітектурному цілому.

Проектних фасадів Острозького єзуїтського колегіуму авторства Джакомо Бріано відомо лише два (рис. 15-16). Вони були опубліковані

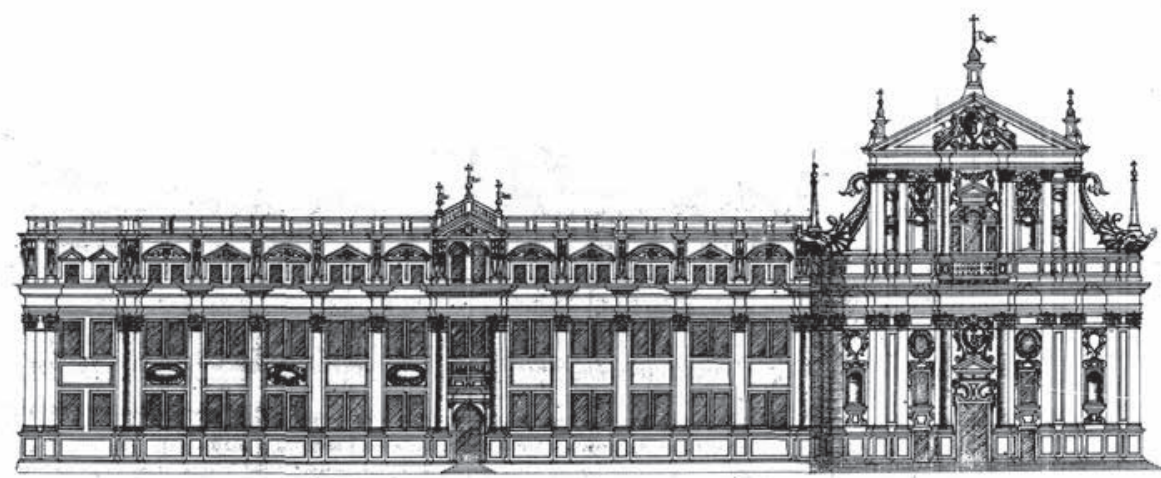

Рис. 15. Проектна версія західного фасаду Острозького єзуїтського колетіуму (?). Арх. Д. Бріано

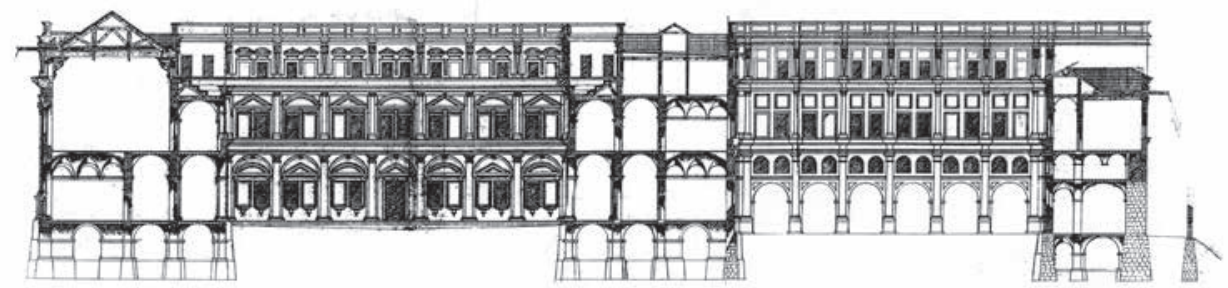

Рис. 16. Проектна версія фасадів та розрізів Острозького єзуїтського колетіуму (?). Арх. Д. Бріано 
Джоном Бурі в антикварному каталозі ще у 1983 році ${ }^{47}$, i охарактеризовані згодом Войцехом Боберським в розгорнутій рецензї ${ }^{48}$. По тому роботи потрапили до Спеціальної колекції музейного Центру Гетті в Лос Анжелесі (США). Хоча вони не мають конкретної атрибуції, однак у дослідженнях Сжи Пашенди пов'язуються саме 3 Острогом. Анджей Бетлей цей зв'язок ставить під сумнів і висуває версію про їх теоретичне призначення ${ }^{49}$.

На нашу думку, обидва документи мають таки острозьке походження. Зокрема, про це свідчить характерна деталь на розрізі по внутрішніх дворах колегіуму (рис. 16), де з правого боку зафіксовано огорожу у вигляді муру, за яким починається стрімке падіння рельєфу. Саме така топографічна ситуація фіксується на обмірних планах Бріано в північній частині земельної ділянки. На той час поблизу муру проходило бічне відгалуження ріки Вілії, якого нині не існує. До того ж серед проаналізованих планів колегіуму бачимо версії з двома внутрішніми дворами, які за своїм розплануванням наближені до цього «фасадного розрізу» (рис. 10-12). I хоча буквального співвіднесення 3 вищенаведеними п'ятьма планами тут не спостерігається, варто пам'ятати, що в нашому розпорядженні немає всіх проектних варіантів комплексу.

Найцікавішим документом виглядає розгортка (рис. 15), що складається 3 чолового фасаду костелу та допасованого до нього зліва триповерхового колегіуму ${ }^{50}$. Дуже незвично виглядають дві волюти у формі «морських монстрів» (дельфінів), котрі з обох боків фланкують верхній ярус композиції 3 невеликими обелісками, встановленими на їхніх головах. Добудований зліва триповерховий колегіум характеризується дуже активними членуваннями фасадних площин - як вертикальними, так і горизонтальними, а ближче до його середини передбачено декоративний ризаліт $з$ автономним входом до споруди. Її перші два поверхи поділені пілястрами коринфського ордеру, поміж якими архітектор вміщує віконні отвори, незвично великі, як для місцевого клімату та тогочасних віконних конструкцій. Натомість третій, аттиковий поверх почленований декоративними кронштейнами, між якими розміщуються значно менші віконні отвори з трикутними та лучковими фронтончиками.

${ }^{47}$ Bury J. Forty-three Sheets of Architectural Drawings by Giacomo Briano da Modena, S.J. (1589-1649): The Society's Architect in Poland and in Northern Italy: a Hitherto Unknown Work of Major Importance for the History of the European Architectural Treatise: a Catalogue. Milano, [1984 ?]. - [24] p.

${ }^{48}$ Boberski $W$. J. Bury, Forty three sheets of architectural drawings by Giacomo Briano... // Biuletyn Historii Sztuki. - Warszawa, 1988. - № 3. - S. 284-286.

${ }^{49}$ Betlej $A$. "Niech przyjdzie tu Witruwiusz ze wszystkimi swoimi następcami". - S.197.

${ }^{50}$ Special Collection of the Getty Center for the History of Art and Humanities (Los Angeles, California). C u/n 4. На звороті аркуша власноручний підпис Бріано "in altro modo la facciata di Chiesa et collegio". 
Незвичною виглядає також та обставина, що аналізоване креслення скомпоноване $з$ двох окремих аркушів, - власне костелу та колегіальної прибудови. Позаяк майже всі горизонтальні членування правого і лівого фрагментів доволі точно допасовані один до одного, таке поєднання може розглядатися лише як комбінаторний спосіб творчого пошуку можливих варіантів, що було і залишається до сьогодні доволі поширеним процедурним прийомом в архітектурному проектуванні.

Варте уваги інше креслення, яке за побічними ознаками можна атрибутувати як розріз по одному з бріанівських варіантів колегіальних приміщень (рис. 16). Як і вищезгадана фасадна композиція, цей документ також є механічною склейкою двох проектних аркушів. Ліва його частина відтворює внутрішній двір атріумного типу з аркадами з усіх боків та 3 триповерховими будинками по периметру. На нульовому рівні атріумного простору по периметру фіксується обхідна галерея з колонадою, до якої з південної сторони припасовано два зальні приміщення, що, в свою чергу, можна вважати прибудовами до вівтарної зони костелу (на кресленні не показаний). Права половина аркуша також має схожий атріумний план, а ще - потужний зовнішній підмурок на рівні першого поверху. Це є очевидне свідчення надання йому оборонної функції, причому значно потужнішої, ніж розташований поруч міський мур.

Порівнюючи фасадну стилістику острозького костелу святих Iгнатія Лойоли і Франциска Ксаверія у версії Бріано з першовзірцем у вигляді знаменитого собору Іль Джезу в Римі, помічаємо цікаву деталь. Робота Бріано, як не дивно, є набагато подібнішою до першого проекту римського храму, виконаного архітектором Віньйолою (1507-1573), аніж до реалізованої пізніше споруди 3 істотними корективами його учня Джакомо делла Порта $(1532-1602)^{51}$. Спроба аналітичного співставлення цих креслень в однаковому масштабі переконливо це доводить (рис. 17). Імовірним поясненням такого творчого наслідування може бути свідома орієнтація Бріано саме на віньйолівський проект, а не на фактично завершену споруду. Виразні стилістичні паралелі прослідковуються і в побудові двоярусних фасадних композицій, які завершуються трикутними фронтонами, і в схожій ритміці накладних декоративних пілястр, і в тричленній організації входів до храму, i в характерних увігнутих волютах в місцях переходу від першого до другого ярусу. Фактично ці два варіанти віддзеркалюють перехідний етап між пізнім італійським маньєризмом і повномірним бароко. Стилістична сутність цієї еволюції проглядається в наростанні архітектурного декоративізму за рахунок більш примхливої деталізації другорядних фасадних елементів. Не останнє значення має і символічне переміщення єзуїтського логотипу „IHS“

\footnotetext{
${ }^{51}$ Levy E. Jesuit Architecture worldwide. A Culture of Corporate Invention // Companions to the History of Architecture / Ed. by H.F. Mallgrave. - Wiley Blackwell, 2017. - Vol. 1. - P. 344-345.
} 

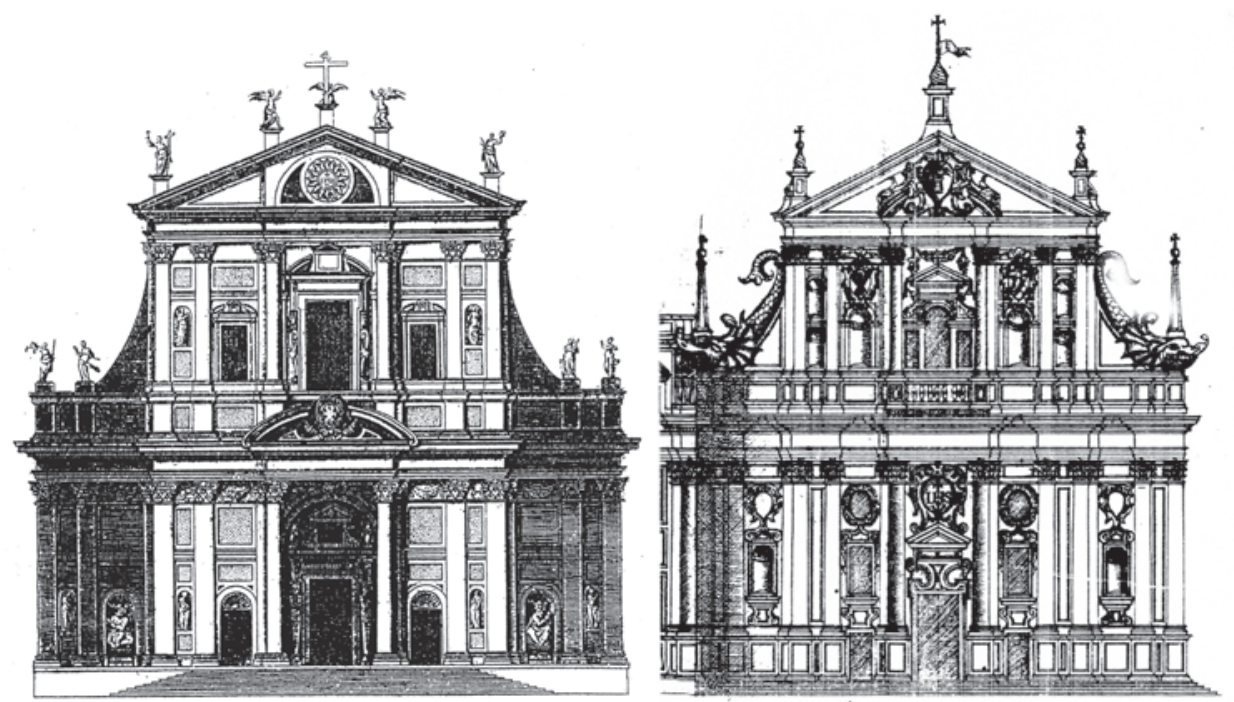

Рис. 17. Компаративне співставлення проектних фасадів: иеекви Іль Джезу в Римі, арх. Д. Віньйола, 1568 (зліва) та костелу Острозького єзуїтського колегіуму, арх. Д. Бріано, 1631 (справа)

3 невеликого картушу на горішньому трикутному фронтоні (у Віньйоли) на вишуканий причілок безпосередньо над головним входом (у Бріано).

Отже, маємо констатувати, що творча спадщина Дж. Бріано, пов'язана 3 Острогом ${ }^{52}$, засвідчує найбільш напружений, доволі суперечливий, однак багатий на креативні задуми етап в архітектурній історії місцевого колегіуму. В підсумку ці задуми залишилися на папері, а багаторічна праця, направлена на пошук та впровадження оптимальних проектних рішень в реальне життя, лягла згодом на його наступників - Мацея Маїка, Бенедикта Моллі та інших майстрів. Без сумніву, усі вони були обізнані з попередніми пропозиціями Бріано, як, вочевидь, і з усіма критичними зауваженнями до них, висловленими представниками Товариства та Анною-Алоїзою Ходкевич.

На відміну від свого попередника, Бенедикт Моллі виявився більш розсудливим та дипломатичним у стосунках з фундаторкою. 3 усього видно, що йому вдалося знайти спільну мову з княжною, котра неодноразово виказувала йому своє прихильне ставлення і щедро винагороджувала за працю. Після приїзду до Острога архітектор потурбувався про підсилення фундаментів, яким, на його думку, не вистачало необхідної глибини закладання. Окрім

52 У фондах Національної бібліотеки Франції зберігається вісім креслень Острога авторства Д. Бріано (№ 134247, 134249-134253, 134257, 134261). Три 3 них є обмірами земельної ділянки. Декілька оригінальних креслеників Бріано, зв'язок яких з Острогом не $\epsilon$ певним, знаходяться в спеціальній колекції Культурного центру Жана-Поля Гетті (Лос Анжелес, Каліфорнія). 
того, вирішено скоригувати намір Бріано підняти цоколь костелу дещо вище прилеглого до нього колегіуму. Виходячи, очевидно, з суто функціональних міркувань, Бріано вивів їх на одну відмітку, розібравши на декілька стоп вже готові зовнішні мури костелу. В цілому ж спорудження колегіуму просувалося значно швидше, ніж костелу. Коли в 1648 році козацькі загони увійшли до міста, єзуїтський храм все ще височів голими стінами, не маючи навіть склепінь ${ }^{53}$. Будівельні роботи завершилися лише на початку XVIII ст. Унікальний комплекс став для Острога виразною архітектурною домінантою (рис. 18), а його розпланувальне рішення з одним дворовим простором (рис. 19) та характерна стилістика двох перших ярусів храмового фасаду (рис. 20-21), засвідчили відголоски тих творчих ідей, співавтором яких можна визнати також і Д. Бріано.

На жаль, доля визначного архітектурного комплексу в подальшому склалася трагічно. Після ліквідації ордену в 1773 році і неодноразових змін функціонального призначення будівля була приречена. Через сто літ російський чиновник так описував цілу споруду: «здание местами двух и трехэтажное, из кирпича и камня, все в украшениях коринфского ордена..., несмотря [на то], что после пожара оно остается без крыши, не только стены, но и своды еще целы, здание исправить можно, но требует огромной суммы, которой в виду не имеется..., сломка этого зданиея по твердости стен будет дорого стоить, и едва ли не дороже материала, который получится» ${ }^{54}$. До початку $\mathrm{XX} \mathrm{ст.} \mathrm{будівля} \mathrm{вже} \mathrm{повністю} \mathrm{була} \mathrm{розібрана.}$

Замість висновків. Наостанок варто повернутися до причин і змісту творчих розбіжностей, які виникли між Анною-Алоїзою Ходкевич та Джакомо Бріано, і породили нечуваний факт в історії тогочасної архітектури, - виконання більше десятка проектних варіантів, жоден 3 яких не був схвалений замовницею. Як видається, суть непорозуміння корінилася не лише в суб'єктивних чинниках. Беручи до уваги увесь доступний масив бріанівської архітектурної графіки, створеної в Острозі протягом 16301632 pр., можна зафіксувати наступні, критично важливі фактори творчої поразки амбітного італійського майстра.

По-перше, в описуваний період мистецьке та архітектурне середовище Острожчини i, ширше, усієї Правобережної України залишалося у сфері активних впливів православної архітектурної традиції. В просторовому домені Острозьких її яскравими «орієнтирами» були два унікальні храми, збудовані знаменитим предком Анни-Алоїзи гетьманом Костянтином Івановичем у родовому гнізді (Богоявленський собор) і сусідньому Межиричі (Троїцька церква). Слід думати, що навіть для молодої католички видавався неможли-

\footnotetext{
${ }^{53}$ Załęski S. Jezuici w Polsce. - Lwów, 1905. - T. 4, cz. 3. - S. 1257.

${ }^{54}$ Центральний державний історичний архів України в Києві. - Ф. 442, оп. 75, спр. 207, арк. 4-5 (1878 р.).
} 


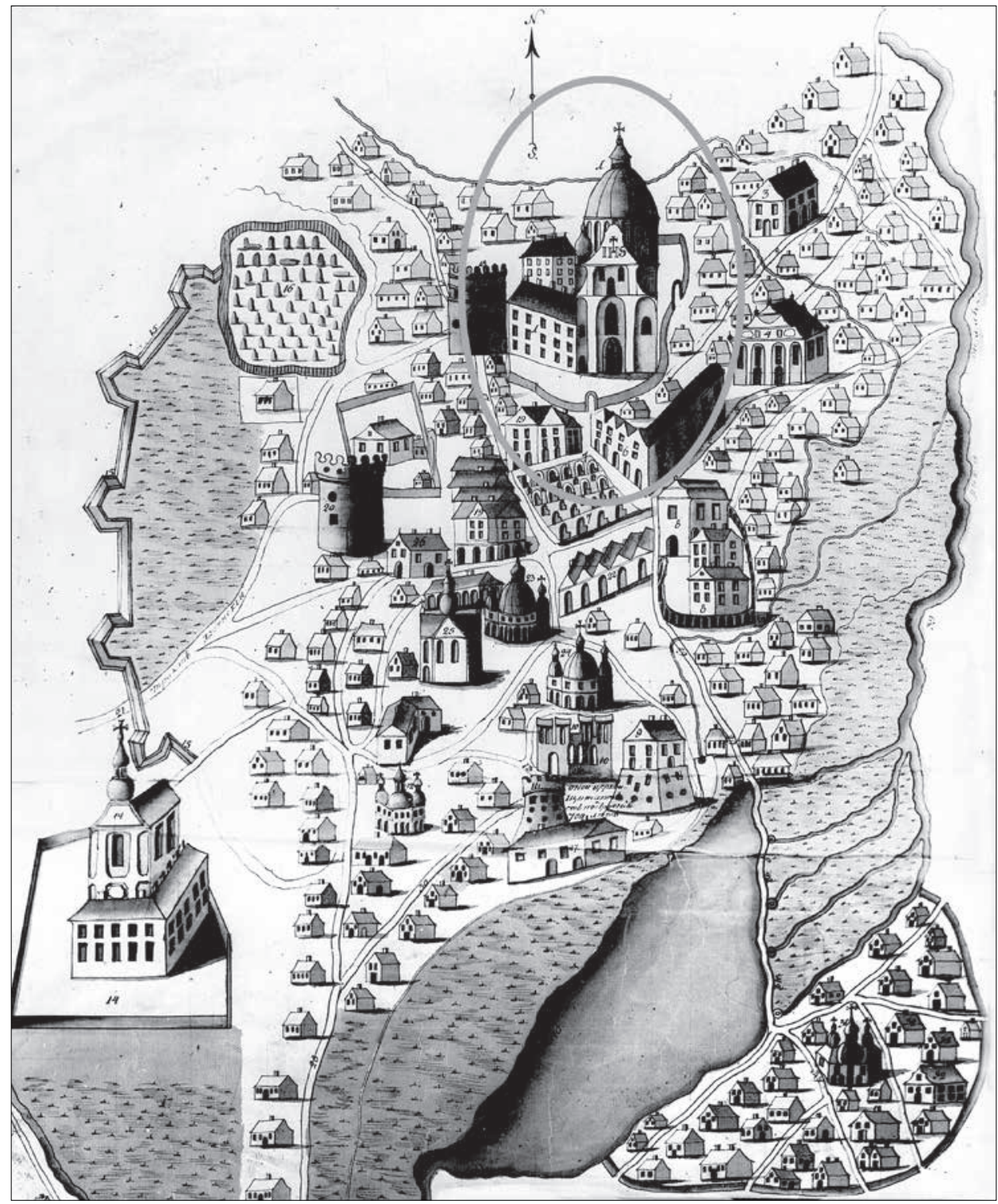

Рис. 18. Загальний вигляд Острога в кінці XVIII cm. з поєзуїтським костелом та колегіумом в ролі архітектурної домінанти міського середовища 


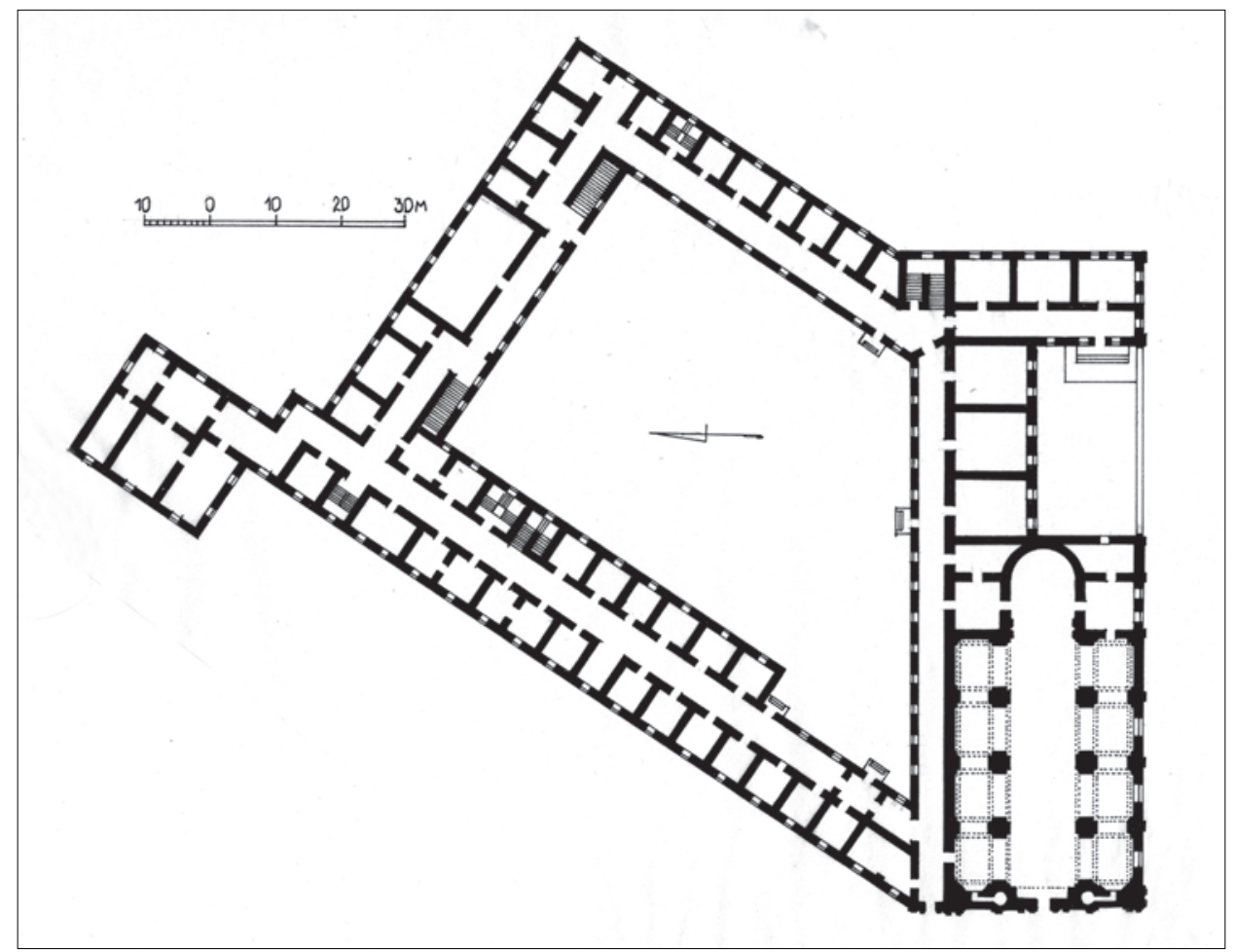

Рис. 19. Обмірний план поєзуїтського колегіуму та костелу.

Середина XIX cm.

вим радикальний розрив з мистецькими уподобаннями своїх предків і беззастережне сприйняти стилістичних форм «іноземного» італійського бароко, яскравим адептом якого, власне, i був Джакомо Бріано.

По-друге, існував очевидний дисбаланс між явною схильністю виконавця замовлення до архітектурного монументалізму і доволі камерним урбаністичним середовищем Острога, цілковито неспівставним 3 тогочасними осередками Товариства Ісуса в Західній та Центральній Європі. Проектні варіанти, запропоновані Бріано, вражають своїм архітектурним масштабом та примхливими формами північно-італійського бароко, однак і масштаб, i стилістична фантазійність автора краще личили б великим містам Італії, а не периферійному Острогу на теренах православної Волині.

По-третє, вочевидь, не останнє значення мали обсяги матеріальних та фінансових витрат, необхідних для реалізації бріанівських задумів. В цьому сенсі, мабуть, навіть далеко не бідній Анні-Алоїзі Ходкевич важко було уявити, а тим більш ухвалити гігантський кошторис будівництва монументального комплексу. 


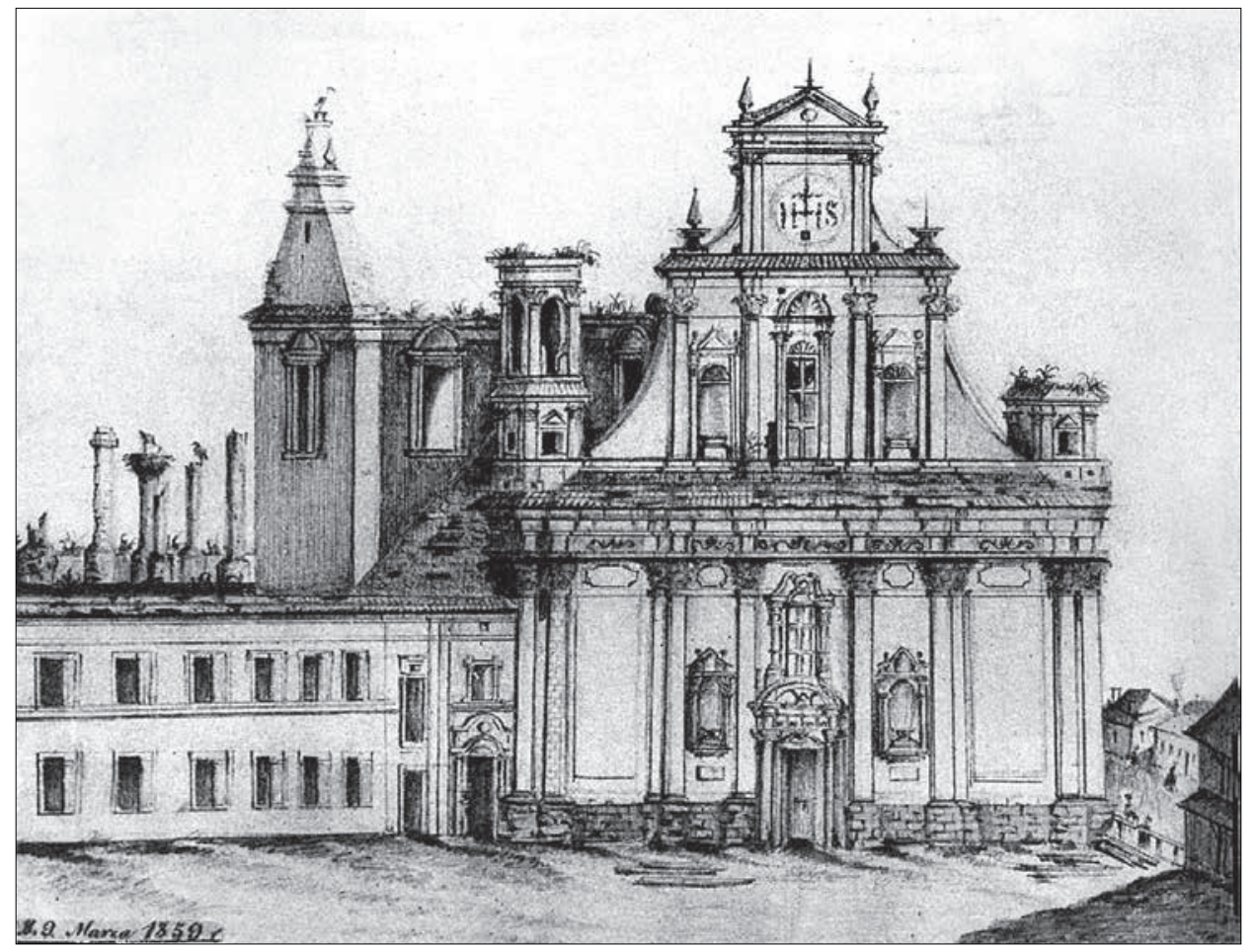

Рис. 20. Остріг. Руїнований головний фасад Острозького поєзуїтського костелу. Середина XIX $\mathrm{cm}$.

Нарешті, характеризуючи діяльність єзуїтів в Острозі, варто зауважити також суспільний чинник - ставлення місцевого населення до архітектурних планів Товариства Ісуса. На цю тему в свій час влучно висловився Станіслав Заленський (до речі, член Ордену), який визнав, що православна людність не надто шанувала пропагандистську активність місіонерів, супроводжувану демонстраціями показної набожності з пишними процесіями, численними оркестрами, театральними виставами та феєрверками. «Дивлячись на все це, Русь, немов би навмисне зневажена в своїй злиденності, наповнювалася жалем, заздрістю та ненавистю до єзуїтів. Тож коли вибухнуло козацьке повстання, та сама людність руська, прилучившись до нього, з насолодою громила та нищила те, що було створене іiі ж власними руками» ${ }^{55}$.

Іноді стверджується, що при спорудженні єзуїтських резиденцій та колегій активна роль, зокрема, в питанні стилістики, належала їх фундаторам

${ }^{55}$ Zatęski S. Jezuici w Polsce. - Lwów, 1905. - T. 4, cz. 3. - S. 1259. 


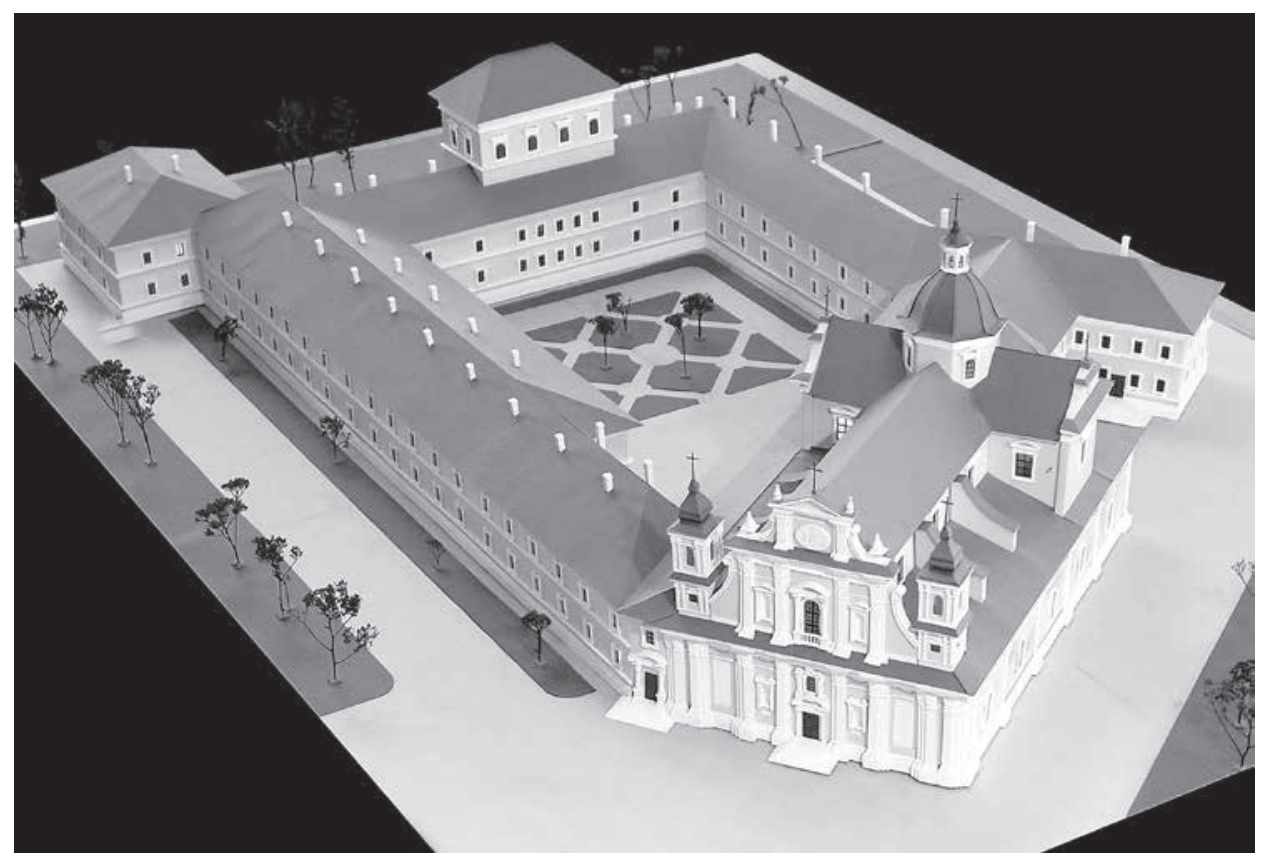

Рис. 21. Загальний вигляд Острозького єзуїтського колетіуму в кінцевій реалізації. Сучасний макет

та патронам ${ }^{56}$. Звичайно, такі суб'єктивні впливи мали місце, однак вони не могли ігнорувати вже сформовані орденські традиції. Конкретно в Острозі, схоже, маємо приклад протистояння «локалізованої» архітектурної візії Анни-Алоїзи Ходкевич і пізньобарокових «монументальних» амбіцій архітектора Джакомо Бріано. Тому, на нашу думку, одним з джерел конфронтації з архітектором були ії династичні архітектурні вподобання, які недостатньо гармонізувалися зі стилістичними смаками амбітного архітектора, уродженця далекої італійської Модени. До того ж, як свідчить, наприклад, одна 3 вищезгаданих проектних версій колегіуму (рис. 13, 14), йому була властива надмірна тяга до гіперболізації та стилістичної комплікації, - навіть там, де такі якості виглядали явно недоречними.

В цьому контексті варто також наголосити специфічну роль так званого «єзуїтського стилю», або, принаймні, більш абстрактного поняття «єзуїтського модусу» в сакральному архітектурному формотворенні. Правомірним $€$ твердження, що навіть якщо орден і не практикував видання конкретних приписів щодо преференцій в архітектурному формотворенні, тим не менш «Товариство було цілком свідомим щодо своїх власних форм і вва-

\footnotetext{
${ }^{56}$ Betlej A. Jesuit architecture in Polish-Lithuanian Commonwelth... - P.280.
} 
жало їх розповсюдження корисним для плекання єдиного, спільного сенсу і цілей Ісуса» ${ }^{57}$.

Сьогодні неможливо з'ясувати всі перипетії своєрідного «змагання» архітектора та меценатки. Чоловік із непростим характером, Д. Бріано, очевидно, і сам був причетний до загострення конфлікту. Сучасникам він запам'ятався як людина темпераментна, гарячкувата, часто нестримана в спілкуванні. Перед орденською адміністрацією в певний момент навіть стояло питання про його виключення з Товариства через побиття робітників на будівництві. Втім, майстер часом сам жалівся, що орденська адміністрація змушувала його брати до рук кельму ${ }^{58}$. Не можна не відзначити також і факти критичної оцінки діяльності архітектора з боку колег по цеху «елітного» рівня, які закидали йому фахову посередність і навіть дилетантизм, що, втім, можна розцінювати і як прояв конкуренції ${ }^{5}$.

Підсумовуючи наше дослідження, варто наголосити на тому, що саме завдяки проектній праці Джакомо Бріано маємо в українській архітектурній історії найдавніший повномірний компендіум фахової архітектурної графіки. Тим не менш, майже чотири століття, які відділяють нас від заснування Острозького єзуїтського колегіуму і його перших проектно-будівельних етапів, все ще інтригують своїми творчими мотиваціями і конкретними практичними обставинами, що супроводжували появу цього унікального об'єкту. Відомо, що згодом в реалізації задуму були задіяні інші досвідчені архітектори і будівничі, однак саме праця Джакомо Бріано була однією 3 важливих передумов архітектурного становлення цілого комплексу.

${ }^{57}$ Levy E. Jesuit Architecture worldwide. - P. 362.

${ }^{58}$ Poplatek J., Paszenda J. Słownik jezuitów artystów. - S. 92.

${ }^{59}$ Bösel R. Typus und Tradition in der Baukultur... - S. 246. 